NBER WORKING PAPER SERIES

\title{
CAPITAL FLOWS, CREDIT BOOMS, AND FINANCIAL CRISES IN THE CLASSICAL GOLD STANDARD ERA
}

\author{
Christopher M. Meissner \\ Working Paper 18814 \\ http://www.nber.org/papers/w18814 \\ NATIONAL BUREAU OF ECONOMIC RESEARCH \\ 1050 Massachusetts Avenue \\ Cambridge, MA 02138 \\ February 2013
}

This paper is forthcoming in a special issue on the "History of Financial Crises" in the Revista de Historia de la Economía y de la Empresa being published and supported by the Archivo Histórico-BBVA (Banco Bilbao Vizcaya Argentaria)-Spain. Comments from the editor, two referees, Michael Bordo, Charlie Calomiris, and Alan M. Taylor were very helpful. The author remains responsible for all errors and omissions herein. An honorarium of less than $\$ 5,000$ was paid to the author for this research by the Archivo Histórico-BBVA. The views expressed herein are those of the author and do not necessarily reflect the views of the National Bureau of Economic Research.

NBER working papers are circulated for discussion and comment purposes. They have not been peerreviewed or been subject to the review by the NBER Board of Directors that accompanies official NBER publications.

(C) 2013 by Christopher M. Meissner. All rights reserved. Short sections of text, not to exceed two paragraphs, may be quoted without explicit permission provided that full credit, including $\odot$ notice, is given to the source. 
Capital Flows, Credit Booms, and Financial Crises in the Classical Gold Standard Era

Christopher M. Meissner

NBER Working Paper No. 18814

February 2013

JEL No. E5,E65,G01,N10,N20

\section{$\underline{\text { ABSTRACT }}$}

The classical gold standard period, 1880-1913, witnessed deep economic integration. High capital imports were related to better growth performance but may also have created greater volatility via financial crises. I first document the substantial output losses from various types of crises. I then explore the relationship between crises and two forces highlighted in the recent literature on financial crises: international capital movements and credit growth. Neither factor is sufficient to explain financial crises in this period. Instead, interactions between the informational environment, the fiscal situation, the exchange rate regime, and events beyond a nation's borders all help explain crises. Some examples are provided.

Christopher M. Meissner

Department of Economics

University of California, Davis

One Shields Avenue

Davis, CA 95616

and NBER

cmmeissner@ucdavis.edu 


\section{Introduction}

Financial crises are an enduring phenomenon in the modern economy. It was during the $19^{\text {th }}$ century, and, in particular, in the heyday of the international gold standard (1880-1913) and globalization that the world witnessed at least two major global financial crises and innumerable local crises. These crises came in several formats. Banking crises led to losses to creditors and depositors alike but also had broader negative impacts in the short and long run. Currency instability gave rise to choppy headwinds for local monetary systems affecting trade and capital flows. Fiscal debacles ending in debt defaults were not unheard of, and often these were related to problems with the exchange rate and the financial system. While the institutional setup and the economic environment are radically different now, observation of the last 30 years' experience with capital flows easily provides some striking similarities to historical events.

This survey first explores the relationship between capital flows and the growth experience. I find that the biggest capital importers had higher volatility in their growth rates than countries with lower capital imports. It is plausible that this volatility was caused by financial crises. I then ask: what caused these crises? I join into a recent debate about whether credit booms or capital inflow bonanzas were major determinants of financial crises. So far this discussion has mainly been focused on crises in recent decades ${ }^{1}$. In my sample, using one plausible econometric specification, neither capital inflows nor a proxy for credit growth are strongly associated with financial crises. Still there is some weak evidence that capital inflows generated higher volatility and a higher probability of experiencing financial turmoil. One of the problems in identifying the effects of credit and capital inflows is that in a small open economy these factors are highly correlated.

If credit and inflows do not go all that far in explaining crises what does? I also emphasize that in the $19^{\text {th }}$ century numerous other forces often cited in the large literature on financial crises also mattered. A good framework for understanding these events is the "third generation" view of financial crises elaborated in the wake of the Asian financial crisis. Without capital flows and leveraged actors, third generation crises are impossible. An appeal is then made to the historical record to illustrate how foreign lending interacted with other fundamentals to generate crises. The paper concludes by asking what we can learn about the past based on the global crisis of 2007 and what the past might tell us about the present.

\section{Contours of the First Wave of Globalization}

The period between 1880 and 1913 witnessed a continuation of the process of global economic integration in international capital and goods markets that was unleashed in the early $19^{\text {th }}$ century ${ }^{2}$. Capital moved across borders free of government controls in this period propelled

\footnotetext{
${ }^{1}$ Jordà, Schularick and Taylor (2011) (JST) is an important exception. They rely on Schularick and Taylor's (2012) path breaking collection of bank loan data for a broad sample of countries. While JST pool data from the last 130 years, I focus only on the period 1880-1913.

${ }^{2}$ Bordo (2003) explores the structure of capital markets. Obstfeld and Taylor (2005) is an excellent guide to international finance since the $19^{\text {th }}$ century. Kindleberger (2005) remains the classic reference on the history of
} 
by a financial infrastructure with global connections based in London, Paris and Berlin. As Europe matured economically, its financial system funnelled savings into foreign government bond issues, railroad equities and debentures as well as myriad other industries and enterprises.

Cross border market-based financing for projects in both the developed and the lessdeveloped regions played an important role in shaping economic outcomes of the recipient countries. Foreign capital helped build up the local capital stock and social overhead infrastructure, funded residential investment, and unleashed the potential of many newly settled export-based countries. Foreign capital also allowed governments to fill revenue gaps in times of war and economic turbulence and at times it indulged the extravagance of local governments.

These global flows also affected local policy. Countries increasingly coordinated on the gold standard to provide an umbrella of stability for capital flows and commodity trade. By 1880, the leading countries of the world had all given up silver or bimetallic systems while by 1900 the leading countries in Latin America and Asia had also joined the bandwagon (Meissner, 2005).

At the core of the global economy was Great Britain with a vast surplus of domestically produced loanable funds. This funding was channelled through the City of London to borrowers from all over the world. Gross (and net) inflows were large even by contemporary standards. On average the current account deficit (relative to GDP) in the principal receiving countries such as Argentina, Australia, Canada, New Zealand, and the US (although in the latter this was mainly prior to 1860), was on the order of three per cent and much higher in many years. In the so-called periphery, the levels were somewhat lower in absolute value but still significant in certain years. Foreign investment often accounted for about 20 per cent of gross investment in the typical developing country of the time and up to 50 per cent in Argentina, Australia, Brazil, and Canada.

Great Britain exported the majority of capital flows while France, Germany, Belgium, and Holland provided smaller amounts. In Great Britain the current account surplus never fell below one per cent of GDP and averaged over four per cent of GDP the entire period. France was the second largest capital exporter at the time. The volumes exported were about half those of Britain.

Clemens and Williamson (2004) demonstrate that factor endowments mattered for the direction of these capital outflows. Australasia, Canada, and other new world regions which received heavy inflows relative to local GDP were richly endowed in natural resources, high in human capital, recipients of large in-migration of young men active in the labor force. Investors expected, and earned, a high rate of return with relatively little risk and large diversification benefits. According to Goetzmann and Ukhov (2006) British investors in the late $19^{\text {th }}$ century could have earned $5.21 \%$ with a standard deviation of $3.89 \%$ on domestic investments. A diversified portfolio with foreign investments attained a much better return-risk ratio with an average return of 5.02\% and a standard deviation of only 2.4\% (i.e., a higher Sharpe ratio). There is every indication that British investors did in fact take advantage of these opportunities as the literature on capital movements in the nineteenth century shows.

\section{Capital Flows \& the Receiving Economies}

If European investors benefitted from investment, what was the impact on the receiving countries? One question is whether capital inflows raised long-run average growth rates as they

financial crises. Reinhart and Rogoff (2009) provide an intriguing new analysis of financial crises over the long run and provide one comprehensive chronology of these events back to the middle ages. 
might have if they helped build up the capital/labor ratio. Schularick and Steger (2010) found that capital inflows raised the rate of economic growth in the late $19^{\text {th }}$ century by raising the rate of investment. Bordo and Meissner (2011) found evidence that bursts of capital inflows in the $19^{\text {th }}$ century period were associated with higher incomes in the long-run and temporarily higher growth rates as a neoclassical model would predict. Both of these papers, and a wider qualitative economic history literature, support the idea that foreign capital mattered for development. This is quite a contrast with the modern literature that studies the period between 1972 and the present and which has not isolated any significant positive growth impact of capital inflows.

Figures 1 through 5 present data on growth in output per capita, growth in consumption per capita (and their standard deviations), and investment rates for the $19^{\text {th }}$ century with a focus on data from a sample of 10 countries for which more than 29 years (1885-1913) of investment, consumption and output data are available ${ }^{3}$. We break the sample into five quintiles based on the within country average ratio of gross capital inflows to GDP between 1880 and 1913. The countries in each quintile from highest to lowest capital inflow recipient are: Argentina and Canada, Norway and the US, Demark and Japan, Italy and Sweden, and France and Germany. I used the London capital calls data from Stone (1999) to measure capital inflows, and I scaled these flows by local GDP as in Bordo and Meissner (2011).

Figure 1 shows that the average growth rates do not seem to vary significantly amongst the lowest four quintiles. However, the highest quintile seems to have enjoyed significantly higher growth rates of output per capita and consumption per capita (Figure 2). Figure 3 shows that investment rates were fairly similar between the quintiles suggesting that some capital inflows were not always used for productive purposes. If anything, investment rates seem noticeably higher than the average in the lowest quintile-two net surplus countries France and Germany.

One other feature of the data is clear in Figures 4 and 5: higher growth in output per capita and consumption per capita for the high capital importers seems to come at the cost of higher volatility. In the highest quintile (Canada and Argentina), the volatility of growth of both output per capita and consumption per capita is two to three times higher than in the bottom four quintiles. The volatility of output growth also seems to be positively associated with the general level of exposure to capital flows. Such volatility was significantly higher in the third (Denmark and Japan) and fourth quintiles (Norway and the US) compared to the bottom and second quintiles. One reason volatility was higher is very likely the fact that capital inflows played a role in heightening the probability of a crisis as suggested in Bordo and Meissner (2011). Of course the pattern of specialization - itself an ultimate driver and consequence of financial globalization may have played a role too. A first cut at this proposition is investigated below. First I turn to an examination of output losses in the wake of financial crises.

\subsection{Output, Consumption and Investment Losses after Crises}

\footnotetext{
${ }^{3}$ Data on output and consumption are from Barro and Ursúa (2008). Investment data are those underlying Taylor (2002).
} 
The academic literature on contemporary financial crises largely supports the idea that financial crises are often accompanied by economic downturns. Many authors cite financial panics and crises as the cause of economic downturns ${ }^{4}$. Bordo, Eichengreen Klingebiel, and Martínez-Peria (2001) looked at the long-run evidence and found that financial crises (banking, currency and twin crises) were associated with cumulative output losses of 9.8 percent. Cumulative output losses were measured as the difference between actual and trend growth from the onset of the crisis to the return of growth to its trend.

No such historical study has been undertaken for debt crises, but the modern literature also finds defaults are associated with lower growth. Borensztein and Panizza (2008) find that growth is 1.2 percentage points below average in the aftermath of a default for at least one year. One has to be cautious about causality here since, as they observe, defaults often come at the tail end of a recession or recessions cum financial crises.

Figure 6 presents graphic evidence on the output costs of crises between 1880 and 1913. Data on output are from Barro and Ursúa (2009). I graph the arithmetic average of the log of the output indexes for the subset of countries that experienced a financial crisis. The sample of crisis countries varies by type of crisis. The criterion used is that output per capita data be available for six years before and seven years after a crisis event. A trend line for each kind of crisis is found by averaging the growth rates over the four years leading up to two years before a crisis (i.e., average growth of output for the interval $[T-5, T-2]$ where $T$ is the year of a crisis). Panel A of Figure 6 suggests that output turns down preceding crisis events, but that crisis years see output roughly 4 percentage points below their trend levels. Within two years, countries on average appear to return to trend. The output gap in the year following banking crises (Panel B) appears to be on average only 1 percentage point while for currency crises (Panel C) the gap is roughly 3 percentage points. Panel D shows a negative trend rate of growth in the run-up to debt crises. Debt crises appear to be the culmination of an economic downturn, rather than the proximate cause. One reason for this is that debt crises in our sample follow currency and banking crises which are themselves associated with below average growth. Following the same methodology as above, Figure 7 analyses the evolution of consumption before and after the various kinds of crises. Panel A presents evidence for all crises combined. The contrast between consumption and output is startling. While Figure 6 showed that output was somewhat lower following a crisis, consumption does not seem to decrease on average. This is as true for banking crises as it is for currency crises (Panels B and C). While on average consumption was only slightly lower following a debt crisis this obscures one outlier. For Argentina, consumption was 17 percent below trend in 1890 in the run-up to the Baring crisis. Consumption actually begins to decline in the years before the default events.

Figure 8 illustrates the evolution of the ratio of investment to GDP using the same methodology except that here the focus is on the average levels of the ratio prior to the crisis rather than the growth rate. It is evident from Panel B that banking crises have a larger impact on investment rates than currency crises. This is consistent with the notion that banking crises in the $19^{\text {th }}$ century were associated with a process of financial disintermediation. On the other hand, currency crises often simply reflected financial market volatility. Many of the "currency crises" in the data are defensive rises in short-run interest rates to stave off currency speculation.

\footnotetext{
${ }^{4}$ Calomiris and Hubbard (1989) show that falling industrial output preceded banking panics in the US prior to 1913.
} 
Currency crises may have been associated with reserve losses which might eventually be sterilized (at least for the short-run) by an active central bank if necessary. Debt defaults also seem to be associated with lower investment in the years following such an event.

\section{Bonanzas vs. Financial Fiestas}

I now turn to a discussion of the links between capital flows, credit, and financial crises. In fact, there is significant debate in the international finance literature on whether capital inflows sow the seeds of a financial crisis. Heavy capital inflows expose countries to the possibility of a "sudden stop" whereupon a rapid improvement in the current account is forced onto a country via a large compression in expenditure and consumption and a sharp exchange rate depreciation. Depreciation in turn poses a further challenge to economies that have built up large liabilities denominated in foreign currency ${ }^{5}$.

Reinhart and Reinhart (2008) note that capital inflow "bonanzas" (i.e., periods of high capital inflows) elevated the probability of a banking crisis in a sample of countries between 1960 and 2007. Powell and Tavela (2012) summarize the recent literature and find that portfolio or banking system capital inflows tend to be associated with a higher probability of a financial crises.

Taylor (2012) suggests that the impact of capital flows on crises has been generally overstated. According to Jordà, Schularick and Taylor (2011), over the long run (1880-2010) abnormally high credit growth (what I refer to above as a financial fiesta) is a better predictor of banking crises than large rises in current account deficits. Underlying this view are formal tests comparing the predictive power of growth in the ratio of credit to GDP to changes in the ratio of the current account to GDP (i.e., net capital inflows relative to GDP) in a sample of 14 countries between 1870 and 2008. This finding suggests that domestic forces may be a more important determinant of crises than external factors. The findings from Jordà, Schularick and Taylor (JST) come from a sample comprising four different time periods with very different institutional bases for international capital flows including the laissez-faire first period of globalization, the volatile interwar years, the ultra-stable Bretton Woods period with low capital flows (1945-1971) and the resurgence of un-governed international capital flows in the modern float. Evidence from Bordo, Meissner and Stuckler (2010), looking at a larger set of countries, suggests that capital inflows were a robust determinant of financial crises in a sample confined to the years between 1880 and 1913 and then again in the years between 1972 and 2008. However, they did not test whether credit booms played a role. Moreover JST use a logit specification allowing for country specific heterogeneity which BMS did not use.

\subsection{Other Causes of Crises}

\footnotetext{
${ }^{5}$ Aguiar and Gopinath (2007) study sudden stops in LDCs and argue that changes in trend output can lead to a sudden stop rather than having sudden stops be the determinants of the business cycle. Bordo, Cavallo, and Meissner (2010) explore this issue between 1880 and 1913 century finding that sudden stops associated with changes in the cyclical component of output were often associated with financial crises while episodes with changes in trend output and sudden stops did not often witness financial crises.
} 
The Anglo-American experience of the classical gold standard would suggest (relative) financial stability, smooth adjustment and so forth. However, Britain boasted an exceptionally large economy; it was the world's banker; it was extremely economically advanced and, due to its financial development, it could credibly commit to maintaining gold convertibility. For Great Britain, external forces were not necessarily fundamental nor were they particularly nefarious or challenging (in relative terms) considering these initial conditions. While the gold standard and international capital markets made for stability in the nation that supported the international gold standard, most of the rest of the world, especially that part that participated in the globalization process, was faced with the fact that capital flows were often de-stabilizing. Fiscal policy was pro-cyclical. Moreover, the gold standard inhibited smooth adjustment and transmitted financial crises $^{6}$. Super-imposed on local banking systems that had no recourse to a lender of last-resort, and which were often intimately connected to the fiscal needs of the unstable local political incumbents, the $19^{\text {th }}$ century international financial system was a minefield for the small-open economies of the day.

A fruitful way to understand the instability in the capital importing periphery is to envision British creditors as depositors who entrusted their savings to a foreign country (i.e. the bank). Borrowers aimed to distribute capital amongst many potential projects in order to develop their infrastructure. These projects by and large had low liquidation value in the event that foreign creditors needed or recalled their money in the 'short-run' (i.e, prior to the maturation of a large infrastructure project). Hence global capital markets of the time were prone to instability in the same way that banks are in the abstract world of Diamond and Dybvig (1983). The Diamond and Dybvig (1983) view of banks holds that the time deposit contract and its maturity mismatch are inherently prone to bank runs and hence episodes of collapse.

After the Asian financial crisis of 1997, a new perspective on financial crises was offered (e.g., Krugman, 1999). The third generation view built upon the Diamond and Dybvig model and applied it to global capital markets to explain why sudden stops, banking crises, currency crises and debt defaults tended to be associated. Assume open international capital markets, local firms (financial and non-financial), and sovereigns that leverage themselves via international capital markets and maturity and currency mismatches whereby liabilities are payable in foreign currency. These factors generate financial fragility much in the same way that the time deposit creates the potential for large losses in the Diamond and Dybvig framework.

A crisis occurs when market expectations change. When market actors change their expectations (for whatever reason) and come to believe that the exchange rate might depreciate, this expectation can become self-fulfilling. Actors know that a depreciated exchange rate would lead to solvency problems especially when debt was payable in a foreign currency and exports could not react quickly enough. One equilibrium in this game is for net capital flows to reverse or stop altogether creating a "sudden stop" and sharp reversal in the current account from deficit to surplus. The exchange rate sharply depreciates, and this validates the financial havoc that was expected (Calvo, Izquierdo, and Mejia, 2004).

Of course, this abstract view of the world neglects many important aspects of reality and the country experiences of the day. Calomiris and Hubbard (1989) suggest that in nineteenth century America banking panics and banking failures were preceded by large unexpected

\footnotetext{
${ }^{6}$ See the introduction to the volume by Eichengreen and Flandreau (1997) for a review of the issues.
} 
declines in industrial output and falls in equity markets. Davis, Hanes, and Rhode (2009) echo an earlier literature suggesting that in the $19^{\text {th }}$ century USA, financial dependence in northern and mid-western states interacted with a high demand for money so that harvest shocks created monetary stringency and banking panics. A broader literature on monetary history discusses solutions to this instability including bank branching, tighter regulation, the ability to "suspend convertibility", the availability of a lender of last resort and even deposit insurance. Most of these measures were only partially implemented in the US in the $19^{\text {th }}$ century. On the other hand, Canada enjoyed relative stability partially due to its national branch system.

The literature on currency crises also has many diverse views. Early work in the vein of Krugman (1979) and Flood and Garber (1984) suggested that fiscal deficits combined with an accommodating central bank could break a peg. Second generation models argued that the political will to defend a peg mattered in a world of open capital markets (Obstfeld, 1986).

Third generation models are encompassing views of domestic financial systems embedded in an open-economy. It implies that there are interactions between financial flows and other aspects of the economy. The level of financial fragility, the probability of a crisis, depends not only on capital flows but on the level of indebtedness, the amount of hard currency debt, connections to other economies, the elasticity of demand and supply for exports, and the productivity of the tradeable sectors and so forth. The credit boom hypothesis is not necessarily a story about an open-economy nor about interactions with these underlying variables. Moreover, the theory as to why credit booms are likely to lead crises is underdeveloped in relative terms if not underspecified in absolute terms ${ }^{7}$. To the extent that for small developing economies domestic credit is driven by capital inflows however, the credit view might not be inconsistent with the capital flows view.

\subsection{Frequency of Crises}

Table 1 presents dates for three types of financial crises: banking, currency and debt. Dates for banking and currency crises come largely from Bordo, Eichengreen, Klingebiel and Martínez-Peria (BEKM) (2001) with one exception listed in the notes to Table 1. Debt crisis dates are from Reinhart, Rogoff and Savastano (2003) and Beim and Calomiris (2001) with two exceptions noted in the notes to Table 1 . A banking crisis occurs when there is a systemic event in the financial sector involving significant losses to the capital of active banks, significant numbers of bank failures, or widespread bank runs. Currency crises were dated by BEKM using an exchange market pressure index together with narrative evidence. This allows for sharp depreciations of the nominal exchange rate, but the methodology can also signal an event when short-term interest rates rise sharply or reserves fall significantly. Debt crises involve rescheduling of the central sovereign's foreign debt obligations, arrears on these liabilities or outright repudiation on any or all of the debt.

\footnotetext{
${ }^{7}$ Borio and White (2003) develop one narrative, reminiscent of Minsky's earlier thoughts, of how “imbalances” can sow the seeds of a crisis. The key idea seems to be that for a given distribution of financial and real shocks the economy becomes more vulnerable to panic and sharp changes in the level of lending at higher levels of debt.
} 


\subsection{Dating Credit Booms and Capital Inflow Bonanzas: Development and Instability}

To identify credit booms, I created an indicator taking the value of one when there is significantly fast growth in the real stock of broad money. Specifically, I used the growth rate of broad money from the BEKM data set and subtracted the rate of inflation to arrive at an approximation of the growth rate of the real money stock ${ }^{8}$. Following Reinhart and Reinhart, I then found the $80^{\text {th }}$ percentile for each country. When the growth rate was at or above this cutoff, that year's value was classified as a boom year.

Lacking credit in a larger more representative sample, I turn to the growth of the real stock of broad money which is available in the BEKM data set for more countries. The growth of the money stock is used in lieu of the credit stock, but ostensibly this is a reasonable choice. Schularick and Taylor (2011) provide data for the growth of money and credit for a sample of 14 countries for a total of 428 country years prior to 1914 noting that "money growth and credit growth were essentially two sides of the same coin". The growth rate of the real stock of broad money from the larger BEKM dataset is highly correlated with similar data from Schularick and Taylor's data (rho $=0.76, \mathrm{~N}=416)^{9}$.

Table 2 shows money and inflow boom indicators by year or sets of years across countries. I focus on a sample of 14 countries/colonies for which we have 33 years of capital inflows (1880-1913) and 33 years of money growth (1881-1913) ${ }^{10}$. Figure 9 shows the aggregate share of the 14 countries that experienced either kind of boom along with the total number of crises (in these 14 countries) in any given year (banking, currency, twin-banking and currency together or in consecutive years, and debt crises). Two global booms and crisis periods are visible in Figure 9. The financial meltdown of the early 1890s followed a peak in global capital inflows between 1887 and 1889. Argentina, which is not in the data underlying Figure 9, had both a money and an inflow boom in these years and this country was at the heart of the debacle that brought the London house of Baring to its knees in 1890-91 and led to a global slowdown in capital flows. In 1904-1906 there is another surge in the growth rate of real money and credit. This preceded the global crisis of 1907 that emanated out of the US and affected nearly all major financial centers and many countries on the periphery too.

While these two well-known episodes of global financial distress illustrate the potential relationship between inflows, credit and crises, there are many other episodes of boom without bust and busts without international booms. The early 1880s, the period 1894-1895 and the years circa 1900 are all periods of high growth in money in many countries but do not post especially

\footnotetext{
${ }^{8}$ Using the growth of nominal money relative to nominal GDP does not alter my conclusions below. Schularick and Taylor (2012) focus on the growth of real loans whereas Jordà, Schularick and Taylor (2011) focus on the ratio of loans to GDP.

${ }^{9}$ The monetary literature distinguishes between credit and money. In the $19^{\text {th }}$ century, much of the growth of domestic credit was intermediated within the banking system that funded itself by issuing monetary liabilities-either notes or deposits. New sources of funding for banks came on line later in the $20^{\text {th }}$ century as Schularick and Taylor (2012) discuss. In the case of international borrowing, a gold inflow or a rise in domestic deposits could cause a rise in the money supply.

${ }^{10}$ Only 322 observations with both information on capital inflows and credit would be available using Schularick and Taylor's data on credit/bank loans. The 14 countries are (the colonies of) Australia, Austria, Brazil, Canada, France, Germany, India, Italy, Japan, New Zealand, Norway, Spain, Sweden, United States.
} 
large numbers of financial crises. There are also many financial crises that are left "unexplained" since they did not occur during any global lending bonanzas or generalized financial booms as I have classified them here.

To test whether capital inflow booms were associated with crises in the recent past, Reinhart and Reinhart (2008) report the conditional probability of having a crisis given that an inflow bonanza has occurred in the three years preceding or following the current year. I carry out a similar test for both inflow booms and money booms in Figures 10 through 12. These figures plot the percentage of country years divided by total sample years in which there is a banking, currency or any (banking, currency, twin, or debt) type of crisis. Next, as in Reinhart and Reinhart (2008), I condition the sample probability of a crisis on whether a money boom or a credit boom occurred in the preceding three years. The number of crisis years is divided by the total number of boom years to arrive at a conditional probability of a crisis after each kind of boom. As Reinhart and Reinhart argue, if this ratio is larger than the unconditional ratio, then there is support for the idea that booms are a determinant of crises.

While Reinhart and Reinhart found evidence that the conditional probabilities were often significantly higher for all varieties of crises (debt, banking and currency) in their sample, the evidence is not so clear in the late nineteenth century. Only a slight majority of countries have larger conditional probabilities for either type of boom and for any type of crisis. For banking crises (Figure 10), the percentage of countries in the sample having higher probabilities is 57\% (inflow bonanzas) and 61\% (money booms). These percentages slide down considerably for currency crises (Figure 11) going to $43 \%$ and $28 \%$ respectively. If any type of boom matters for currency crises in the gold standard period, it is more likely to be an inflow boom rather than a money boom. Combining all types of crises, Figure 12 again shows that $52 \%$ of countries report a higher ratio after conditioning on capital inflow booms and 52\% when controlling for money booms.

We now look for connections between inflow and credit booms and crises using multivariate limited dependent variable models for the empirical probability of each type of crisis. In Table 3 we report the results from three families of logit models. The first family of regressions models the probability of a banking, currency or any kind of crisis (banking, currency, twin, or debt) as a function of the money boom and inflow boom indicators ${ }^{11}$. For these dummies, three lags of each variable are included. In columns 3-6 of Table 3, other determinants of financial crises studied in Bordo and Meissner (2011) are included. The first is the ratio of foreign currency debt to total debt which controls for currency mismatches. The next variable indicates whether a country is on the gold standard and maintaining a pegged exchange rate versus the major creditor nations of Europe. The British discount rate is used to control for conditions in the international capital market. Lagged values of these controls are used throughout to avoid simultaneity bias. Finally, lagged values of a currency crisis indicator and banking crisis are included since third generation models of crises link the exchange rate, the financial sector and the sovereign. In columns 7-9 I replace the boom indicators with the rate of change of the (real) money stock and the ratio of capital inflows to GDP.

\footnotetext{
${ }^{11}$ The indicator is one if the ratio of capital inflows to GDP or the growth of real money is higher than the within country $80^{\text {th }}$ percentile in the given year.
} 
None of these specifications provide conclusive evidence that money/credit booms heighten the chances of a financial crisis in this sample ${ }^{12}$. On the other hand, there is some limited evidence that capital inflows were associated with a higher probability of a crisis. The first lagged value of the capital inflows boom indicator, or the level of (lagged) inflows/GDP, is significant and positive in several of the specifications.

Neither the foreign currency debt variable nor the gold standard variable are significant. Bordo and Meissner (2007) found that hard currency debt only raised the chances of a financial crisis when other factors made a country financially fragile. Nations like the USA, Sweden, Canada and Australia, carried debt payable entirely in terms of fixed amounts of gold but avoided the kind of third generation meltdowns evident in the southern cone of Latin America (Argentina, 1890-91; Brazil, 1890-91 and 1897) or in Southern Europe (Italy 1891-93; Portugal 1891; Greece, 1894).

The contemporary literature often argues that fixed exchange rates transmit financial shocks and so heighten the chances of a crisis. The gold standard does not seem to raise the probability of a crisis in the $19^{\text {th }}$ century. National experience was too variable for gold standard adherence to show up directly as a determinant. Some countries managed to hold their pegs even through serious financial turbulence (e.g., USA, 1890-1893, Australia, 1890, Canada 1890-1893, France, 1882, Germany 1893 \& 1907). By holding their pegs, these nations avoided the financial meltdown associated with depreciating currencies and higher debt burdens. Their techniques for maintaining stability varied but often these nations relied upon, playing by the "rules of the game" and cutting back on credit when gold was scarce, cooperative short-term lending or stabilizing speculation on capital markets that would bring gold back.

At times large actors even had recourse to international cooperation relying on stop-gap liquidity support from large financial actors or foreign central banks. The Bank of France and the Bank of Russia offered support to the Bank of England in the midst of the Baring crisis in 1890. Once again, in 1907, the Bank of England relied on assistance from the Bank of France and the Reichsbank $^{13}$. The US made special arrangements with the Belmont-Morgan syndicate in the 1890s and often relied on temporary suspensions of convertibility to ease liquidity problems. By contrast, many other nations in the poor periphery hooked up to the gold standard temporarily, and in times of duress they were incapable of securing assistance from abroad. After crises such nations aimed to restore convertibility but were unable to return to convertibility after suspension. In the southern cone of Latin America, the years before the crises of the 1880s and 1890s involved a large monetary expansion and increase in the price level. Return to the precrisis gold parity was often politically challenging leading to further economic uncertainty and a slow recovery. Monetary expansions in these countries in the late $19^{\text {th }}$ century were often related to fiscal problems and not only Minskian private sector "exuberance". Therefore, in a large

\footnotetext{
${ }^{12}$ To deal with the potential correlation between money growth and capital inflows which might obscure the relationship to crises, capital inflows were omitted. This did not make the coefficient on the money growth variable become more significant. I also found that the growth of the ratio of broad money to GDP, closer to the ratio of credit to GDP used by JST, is also not significant. Also, if I use the cumulative change in Schularick and Taylor's credit variable, in a much smaller sample, credit is a significant predictor of banking crises in the 1880-1913 period. According to personal communication with Alan Taylor, credit data for a broader sample than that in Schularick and Taylor (2012) are currently being collected. These new data will allow researchers to assess whether the credit hypothesis holds up in a broader sample.

${ }^{13}$ Bordo and Schwartz (1999) survey the history of international financial rescues and instances of assistance.
} 
number of countries, a fundamental inability to maintain a sound banking system and balanced fiscal position combined to create the conditions for significant financial instability.

Related to this observation, Table 3 shows that the lagged values of various crises are significant and positive. Countries already engulfed in financial turmoil in part of one year were likely to be racked by such perturbations in the following year providing some support for the third generation view of crises. The discount rate in Britain is also positive and significant such that higher interest rates, and presumably lower capital inflows, contributed to the probability of a crisis in smaller nations. This parallels evidence on the influence of the US discount rate in shaping the onset of the debt crisis of the 1980s and the Asian crisis of 1997.

Given the lack of high levels of statistical significance of most of the explanatory variables included above, the lesson from the econometric models of Table 3 might be that there are few systematic determinants of financial instability in this period ${ }^{14}$. The next section highlights several other determinants of financial crises that are more difficult to fit into a regression framework.

\section{The Bigger Picture: What Else Explains Crises in the $19^{\text {th }}$ Century?}

The preceding section made use of a set of parsimonious models to understand financial crises in the gold standard period. What other factors explain financial crises in the late $19^{\text {th }}$ century? What lessons are there to take from three decades of financial instability?

Perhaps the first lesson is one emphasized by Carmen Reinhart and Ken Rogoff. Crises were an "equal opportunity menace" for countries of all stripes, levels of development and financial sophistication. At some point between 1880 and 1913, virtually every country was hit by some form of financial crisis or instability. Financial activity is risky business. The banking systems of the late $19^{\text {th }}$ century were prone to losses and most of them realized large losses at some point. The stability of the financial sector in the face of realized losses and the spillovers into the real economy varied by country however due to a country's fiscal situation, its institutional foundations, the informational environment, and exposure to global capital markets ${ }^{15}$.

\subsection{Fiscal Crises and Financial Crises}

In many countries there was a fiscal undercurrent to the banking, currency and debt crises that unfolded in $19^{\text {th }}$ century. These fiscal issues came in many forms. At times there was an inability to generate sufficient revenue to cover previous obligations. Argentina, Brazil, Egypt, Portugal, and Turkey all fell victim to such problems at some point between 1880 and 1913. This begs the question of who committed to such obligations and why they did so if they were able to foresee financial catastrophe looming?

\footnotetext{
${ }^{14}$ One might look at goodness of fit measures as in Jordà, Schularick and Taylor (2011) but since most determinants in my models are not statistically significant individually, it is unlikely that these metrics would be very insightful.

${ }^{15}$ Bordo, Redish and Rockoff (2011) discuss the history of Canada's banking sector where systemic crises have been much rarer than in the US. In the $19^{\text {th }}$ century, losses of deposits in both banking systems were similar and yet the US was much more frequently engulfed in systemic financial crises that had an impact on the real economy than Canada was.
} 
As is often the case, political forces may have played a role in exposing countries to financial crises. In the case of Argentina in 1890, political pressures to develop the hinterland, raise land prices and to sustain an unsustainable deficit led to a fiscal debacle (Della Paolera, 1994). Following a recovery from monetary instability in 1885, Argentina, under Roca and then Juárez Celman, embarked upon an ambitious attempt to further consolidate political control at the federal level. In exchange, the provinces gained many concessions including an uptick in education spending (Elis, 2011), loan guarantees to construct railroads ensuring that local producers could more easily access international markets, and a new banking law that allowed for significant monetary expansion that would grease the wheels of aggregate activity. The National Banking of Argentina system rolled out in 1888. This new system allowed 16 new banks to be established on condition that their bank notes be backed by national government debt which itself was supposed to be payable in gold. While this law was supposed to be modeled on the US National Banking system, it in fact differed substantially by design. The most important difference was the fact that bonds backing the note issues of the banks were specially issued rather than being purchased on secondary markets as in the US. In effect, the debt was fully monetized. A "fiesta financiera” ensued coinciding with massive capital inflows from Britain.

The government posted large deficits throughout the period and by 1890 it was unable to honor its commitments to pay off its debts. The government also became incapable of stabilizing the peso as locals rushed to convert paper obligations of the banks into gold. International markets sold Argentinean bonds in a panic. The result was a sudden stop in capital inflows, a currency crisis of epic proportions and a debt default. Baring Brothers London was heavily exposed to Argentina and had to eventually be rescued with a lifeboat operation organized by London banks which was guaranteed by the Bank of England

Events in Brazil in the 1890s followed a remarkably similar trajectory. They also illustrate how deep fiscal and political problems can create massive financial meltdown. The revolution of 1889 de-throned the Emperor creating a republic. Thereupon currency convertibility was abandoned in 1890 and a period of monetary exuberance followed. Banking regulations in the new republic were liberalized allowing for a number of local banks to be established with the nominal money supply rising four-fold between 1889 and 1891. A set of erratic and inconsistent policies was then instituted. Although gold convertibility of the currency had been abandoned, the authorities tried to halt monetary expansion by consolidating the note issue at the Bank of the Republic. Soon after, an outright civil war led to an increase in the funding needs of the government and a consequent a rise in the national debt. In 1892 the Bank of the United States of Brazil was re-chartered leading to further outbreaks of rapid monetary expansion. As the milreis depreciated further, the burden of the foreign debt which was payable in gold increased. By 1898 Brazil was forced into a moratorium on its debt with a radical plan to re-vamp public finances sponsored by the Rothschilds.

Both of these examples from South America demonstrate how a weak fiscal position and governments desperate to shore up support can tempt governments into dabbling with the banking system. The outcome in both of these situations was what we would now call a credit boom. These periods of exuberance (and deficits) were often accompanied by strong capital inflows. Temporarily, their currencies held strong and asset prices remained high. Microeconomic forces sustained the booms as financial firms competed for a slice of the abnormal returns (Flores Zendejas, 2010). Eventually expectations changed, a shock in foreign markets 
occurred, or a real shock at home extinguished the flames of hope. Sudden stops of capital inflows occurred in both cases and the currencies depreciated. Banks that relied on funding from abroad became insolvent. Nations in such dire straits often chose to default on foreign currency debt rather than smother their economies in a difficult re-adjustment via massive expenditure reductions.

\subsection{Information asymmetries}

No discussion of financial markets is complete without reference to the role of asymmetric and incomplete information. Both of these have been cited as reasons why economies are financially fragile. Informational issues undoubtedly contributed to financial instability in the nineteenth century in ways that are difficult to capture in an econometric framework.

Moral hazard and adverse selection were two significant problems prior to 1913. Investors in London, France, and Germany frequently over-estimated the ability and willingness of sovereign and private borrowers to repay. In Australia in the late 1880s and early 1890s, British savers appear to have been duped into thinking that their deposits in the British branches of Australian colonial banks were as safe as they might be in banks operating primarily in the British system. As capital poured into Australia, the seeds of a massive banking crisis were sown. Competition in the Australian banking system between traditional trading banks and land banks generated a massive lending spree. Building societies, mortgage banks and land investment companies sprang up quickly propelling a full-scale property and land boom. Some of the trading banks in Australia connected themselves to the land banks during this period. When the financial frenzy ended, these banks were found to be insolvent.

Although the land boom had ended by 1890, and many smaller mortgage companies had failed, the crisis had yet to run its course. Indeed British deposits in the Australian banking system were increasing as late as 1892. In late 1892 and early 1893, the crisis found its way into the traditional banking sector when the Federal Bank of Australia was liquidated after it suspended payment of specie. The Commercial Bank of Australia had also invested heavily in the land sector. When it suspended payment on its deposits in 1893, over 40 percent of its deposits reportedly belonged to British nationals. The Australian crisis culminated with large losses in the banking sector and a re-capitalization of the remnants of the banking system at the behest of regulators. Some depositors also accepted a conversion of their savings into interestbearing transferable deposits which helped ease the liquidity crunch in the banking sector.

Another colorful example of informational problems is evident in the Comptoir d'Escompte crisis of 1889 in France. Several years earlier, a group of leading French financiers and other financial institutions including the Comptoir d'Escompte, Paribas and the Rothschilds formed a syndicate with the intention of cornering the global market in copper. As copper prices rose, the inevitable temptation to cheat on production targets (i.e., moral hazard) played itself out and new sources of supply came online. The copper price crashed in early 1889. In March 1889 the president of the Comptoir d'Escompte, Denfert-Rochereau committed suicide sparking a run on his bank. The Bank of France was asked to respond with an enormous loan to keep the bank afloat $^{16}$. A contentious debate within the general council of the Bank of France preceded this

\footnotetext{
${ }^{16}$ What follows was greatly informed by Hautcoeur, Riva, and White (2012).
} 
bailout. Opponents suspected conflicts of interest amongst voting members on the Bank of France governing council who also had participated in the copper corner. Eventually however, the loan was approved, and although tough conditionality was meant to be imposed, political battles prevented this conditionality. In the end, of a number of the leading financiers in the copper syndicate faced criminal and financial penalties, while directors of the institutions involved and a board member of the Bank of France were forced to resign (Hautcoeur, Riva, White, 2012). The lack of either government or market-based discipline in the run-up to the crisis suggests that informational problems were rife even in the largest financial centers.

A succession of $19^{\text {th }}$ century crises also reveals the potential for moral hazard. In Italy and in the 1890s a land boom combined with implicit government guarantees which eventually generated large financial losses. The Baring Crisis itself was underpinned by government guarantees of interest on railway bonds and assumption of currency risk by the government. While deposit insurance and other implicit government or international guarantees had yet to be developed in the early $19^{\text {th }}$ century, moral hazard was certainly already a factor.

\subsection{Contagion}

Since the resurgence of international capital flows in the 1970s, the world has suffered at least three international crises: the Latin American debt meltdown, the Asian financial crisis, and the sub-prime crisis. It has been argued that greater financial integration could make financial turbulence spillover directly into other markets that were otherwise not posed for a crisis. A handful of economic history papers have looked for a similar dynamic in the classical gold standard era. Neal and Weidenmier (2003) and Bordo and Murshid (2001) investigated increased co-movement in $19^{\text {th }}$ century financial markets around the time of financial crises. Statistical tests along the lines of Forbes and Rigobon (2002) found that it was difficult to reject the hypothesis of no increase in financial markets co-movement after accounting for the higher volatility of crisis periods. In other words contagion, and even increased co-movement, may have been a statistical mirage.

Still, anecdotal evidence in Neal and Weidenmeir (2003) and Odell and Weidenmier (2004) is suggestive that the global crisis of 1907 was transmitted to third countries via international money markets. Specifically, insurance claims associated with the San Francisco earthquake of 1906 sparked intense demand for gold in London. The Bank of England was then forced to raise its discount rate to avoid gold outflows. Later in 1907, a banking panic erupted in New York in connection with the Trust companies of New York ${ }^{17}$. Before the crisis abated, financial tremors had been felt throughout the world's financial markets from Denmark and France all the way to Egypt and Chile. Kris Mitchener and Marc Weidenmier (2008) also found evidence of contagion in sovereign bond markets. They studied a sample of Latin American bond yields and found a sell-off of Latin American assets following the outbreak in Argentina of the 1890 Baring crisis as if global capital markets shunned geographically proximate emerging markets.

\footnotetext{
${ }^{17}$ The Trust companies, most notably the Knickerbocker in New York City, were identified with a mis-guided attempt to corner shares in the United Copper Company.
} 
As this brief survey highlights, the causes of financial crises were varied and interacted with other shocks to the global economy and to local economies. While some leading determinants can be highlighted, there was a large idiosyncratic component to the financial debacles of the nineteenth century.

\section{Conclusions}

What conclusions can be drawn from this brief survey of financial crises during the classical gold standard period? First, crises were ubiquitous events in the period of globalization that preceded World War I. Could it be that globalization was a primary cause of these crises? Indeed there seems to be some evidence that capital inflows sowed the seeds of banking, currency and debt crises. These inflows then interacted with other weaknesses creating financial fragility or a heightened potential for a crisis. An alternative possibility is that high levels of credit growth fueled unsustainable asset booms raising the potential for crises. There seems to be very little strong evidence that between 1880 and 1913 credit or money growth was a good predictor of financial turmoil across countries in my sample.

Beyond credit and capital inflows, many crises had their origins in local deficiencies. Real and financial shocks mattered too and international events played a large role. Whatever their root causes, there is substantial evidence that a "third generation" view of how crises unfold can help inform our understanding of crises in the $19^{\text {th }}$ century. Expectations, capital market frictions and capital flows combine to create the possibility for the trio of problems encompassing bank failures, currency depreciation and debt defaults. Argentina and Brazil fell victim to this kind of problem in the $19^{\text {th }}$ century but so did Portugal, Greece, and Italy. Others might have fallen victim to these crises but were able to short-circuit total meltdown through effective policy responses.

Should we view the past differently in light of the Subprime crisis that broke out in 2007 and 2008? As various observers have pointed out, one of the key drivers of the crisis and panic on Wall Street was severe informational problems. However, the shadow banking system appears to have been rendered financially fragile due to major regulatory failures that allowed risks to be hidden off balance sheet and for unregulated insurance companies like AIG to buildup mammoth positions in derivatives markets. All of this suggests that it is very useful to understand the micro-structure of financial markets and the role of intermediaries in order to make sense of a financial crisis (Adrian and Shin, 2008). This lesson holds for the $19^{\text {th }}$ century.

Other commentators have also emphasized the role of moral hazard in the recent crisis. This review suggests that guarantees and implicit commitments to bailouts have long existed. An important avenue of research is better understanding the political determinants of moral hazard in the financial sector.

At the macro level, excessive credit growth and capital inflows or imbalances were implicated in the recent crisis. In fact, the relationship between capital inflows to the US, coincident global imbalances, and the recent crisis is rather circumstantial. Some have claimed that capital inflows and ultra-low global interest rates led New York banks to reach for yield 
through sub-prime mortgages. However, central bank policy and regulatory failure undoubtedly played key supporting roles.

A final thought concerns the persistence of crises. We have seen that crises were an important phenomenon throughout the classical gold standard period and few countries were spared. Many countries had multiple events within the 34 year period studied. The question then is why do not countries learn to avoid crises? As a matter of fact, these observations obscure significant differences between countries. Some nations had repeated episodes of crises with similar causes and effects. The US had a series of banking crises throughout this period due to its peculiar banking system. The 1880s and 1890s were very unstable for many Latin American countries. Others had multiple crises but with very different causes. Future research should aim to show whether and why some countries "learn” from financial crises and whether such learning is permanent. The aim here will be to understand what the determinants of learning are so that crises that raise economic volatility and bring welfare losses might not have to endlessly repeat themselves especially in emerging economies where development prospects are often so fragile.

\section{References:}

ADRIAN, Tobias and SHIN, Hyung Song (2008): "Financial Intermediaries, Financial Stability and Monetary Policy” Federal Reserve Bank of Kansas City 2008 Jackson Hole Economic Symposium Proceedings.

AGUIAR, Mark and GOPINATH, Gita (2007): "Emerging Market Business Cycles: The Cycle is the Trend”, Journal of Political Economy, 115, n¹, pp. 69-102.

BARRO, Robert J. and URSÚA, José F. (2008): “Macroeconomic Crises since 1870”, Brookings Papers on Economic Activity, spring, pp. 255-335.

BEIM, David O. and CALOMIRIS, C.W. (2001): “Emerging Financial Markets”, MacGraw-Hill, New York.

BORDO, Michael D. (2003): “The Globalization of International Financial Markets: What Can History Teach Us?”, in AUERENHEIMER, Leonardo (ed.): International Financial Markets: The Challenge of Globalization, University of Chicago Press, Chicago, pp. 29-78.

BORDO, Michael D., CAVALLO, Alberto, and MEISSNER, Christopher M. (2010): "Sudden Stops: Determinants and Output Effects in the First Era of Globalization, 1880-1913", Journal of Development Economics, 91, n², pp. 227-241.

BORDO, Michael D., EICHENGREEN, Barry, KLINGEBIEL, Daniela and MARTINEZ-PERIA, Maria Soledad (2001): “Is the Crisis Problem Growing More Severe?”, Economic Policy, 16 nº 32, pp. 53-82.

BORDO, Michael D., MEISSNER, Christopher M. (2007): “Financial Crises, 1880-1913: The Role of Foreign Currency Debt” in EDWARDS, Sebastian, ESQUIVEL, Gerardo y MARQUEZ, Graciela (eds.): 
The Decline of Latin American Economies: Growth, Institutions, and Crises, University of Chicago Press, Chicago, pp. 139-194.

BORDO, Michael D. and MEISSNER.Christopher. M. (2011): "Foreign Capital, Financial Crises and Incomes in the First Era of Globalization”, European Review of Economic History, 15, n¹, pp. 61-91.

BORDO, Michael D., MEISSNER, Christopher M., and STUCKLER, David (2010): "Foreign Capital and Economic Growth: A Long-Run Comparative Perspective”, Journal of International Money and Finance, 29, no 4, pp. 642-665.

BORDO, Michael D. and MURSHID, Antu (2001): “Are Financial Crises Becoming More Contagious? What is the Historical Evidence on Contagion?” in Claessens, Stijn and Forbes, Kirsten (eds.): International Financial Contagion, Kluwer, Norwell, Mass., pp. 367-406.

BORDO, Michael D., REDISH, Angela, and ROCKOFF, Hugh (2011): "Why didn't Canada have a banking crisis in 2008 (or in 1930, or 1907, or ...)?”, NBER working paper n 17312.

BORDO, Michael D. and SCHWARTZ, Anna J. (1999): "Under what circumstances, past and present, have international rescues of countries in financial distress been successful?”, Journal of International Money and Finance, 18, pp. 683-708.

BORENSZTEIN, Eduardo and PANIZZA, Ugo (2008): “The Costs of Sovereign Default” IMF working paper WP/08/238.

BORIO, Claudio and WHITE, William W. (2003): "Whither monetary and financial stability? The implications of evolving policy regimes”, in: Federal Reserve Bank of Kansas City: Monetary Policy and Uncertainty: Adapting to a Changing Economy: A Symposium. Kansas City, MO pp. 131-211.

BUYST, Erik, MAES, Ivo (2007): “Central Banking in $19^{\text {th }}$ century Belgium: Was the NBB a Lender of Last Resort?”, in Oesterreichische Nationalbank Proceedings of the Second Conference of the SouthEastern European Monetary History Network.

CALOMIRIS, Charles W. and HUBBARD, R. Glen (1989): "Price Flexibility, Credit availability and Economic Fluctuations: Evidence from the United States, 1894-1909”, The Quarterly Journal of Economics, 104, n³, pp. 429-452.

CALVO, Guillermo., IZQUIERDO, Alejandro, and MEJÍA, L. (2004): “On the Empirics of Sudden Stops: The Relevance of Balance-Sheet Effects”, National Bureau of Economic Research Working Paper Series No. 10520.

COMIN, Franciso (2012): "Default, rescheduling and inflation. Debt crisis in Spain during the 19th and 20th centuries” Working paper 12-06 Departamento de Historia Económica e Instituciones ,Universidad Carlos III de Madrid.

DAVIS, Joseph H., HANES, Christopher, and RHODE, Paul W. (2009): "Harvests and Business Cycles in Nineteenth-Century America,” The Quarterly Journal of Economics, 124, nº4, pp. 1675-1727. 
DIAMOND, Douglas and DYBVIG, Philip (1983): "Bank Runs, Deposit Insurance, and Liquidity”, Journal of Political Economy, 91, nº 3, pp. 401-419.

DELLA PAOLERA, Gerardo (1994): “Experimentos monetarios y bancarios en Argentina: 1861-1930”, Revista de Historia Económica, 12, nº 3, pp. 539- 590.

EICHENGREEN, Barry. and FLANDREAU, Marc (1997): “Editor's Introduction” in EICHENGREEN, Barry. and FLANDREAU, Marc. (eds.): The Gold Standard in Theory and History, Routledge: London, pp. 1-30.

ELIS, Roy (2011): "Redistribution under Oligarchy: Trade, Regional Inequality, and the Origins of Public Schooling in Argentina, 1862-1912”, mimeo Stanford University Political Science Dept.

FORBES, Kristin and RIGOBON, Roberto (2002): "No Contagion, Only Interdependence: Measuring Stock Market Comovements”, The Journal of Finance, 57, n5 pp. 2223-2261.

FLOOD, Robert P. and GARBER, Peter (1984): “Collapsing exchange-rate regimes: Some linear examples”, Journal of International Economics, 17, nº 1-2, pp. 1-13.

FLORES ZENDEJAS, Juan H. (2010): “Competition in the Underwriting Markets of Sovereign Debt: The Baring Crisis revisited”, Law and Contemporary Problems, 73, nº 4, pp. 129-150.

GOETZMANN, William N. and UKHOV, Andrey D. (2006): "British Investment Overseas 1870-1913: A Modern Portfolio Theory Approach”, Review of Finance, 2006, 10, nº 2, pp. 261-300.

HAUTCOEUR, Pierre-Cyrille, RIVA, Angelo and WHITE, Eugene (2011): "Bagehot on the Continent? How the Banque de France Managed the Crisis of 1889”, mimeo Paris School of Economics.

JORDA, Oscar, SCHULARICK, Moritz, and TAYLOR, Alan M. (2011): "Financial Crises, Credit Booms and External Imbalances: 140 Years of Lessons”, IMF Economic Review, 59, nº 2, pp. 340-378.

KINDLEBERGER, Charles P. (2005): Manias, Panics and Crashes: A history of Financial Crises. $5^{\text {th }}$ Edition. Wiley, New York.

KRUGMAN, Paul (1979): “A Model of Balance of Payments Crises”, Journal of Money, Credit and Banking, 11, n³, pp. 311-325.

KRUGMAN, Paul (1999): “Balance Sheets, the Transfer Problem, and Financial Crises”, International Tax and Public Finance, 6, n³, pp. 459-472.

MEISSNER, Christopher M. (2005): "New World Order: Explaining the International Diffusion of the Gold Standard, 1870-1913”, Journal of International Economics, 66, pp. 385-406.

MITCHENER, Kris James, and WEIDENMIER, Marc D. (2008): "The Baring Crisis and the Great Latin American Meltdown of the 1890s”, The Journal of Economic History, 68, 02, pp. 462-500.

NEAL, Larry and WEIDENMIER, Marc (2003): “Crises in the Global Economy from Tulips to Today” in Bordo, Michael D., Taylor, Alan. M. and Williamson, Jeffrey G. (eds): Globalization in Historical Perspective. University of Chicago Press, Chicago, pp. 473-514. 
OBSTFELD, Maurice (1986): “Rational and Self-Fulfilling Balance of Payments Crises”, American Economic Review, 76, n¹, pp. 72-81.

OBSTFELD, Maurice and TAYLOR, Alan M. (2005): Globalization and Capital Markets: Integration, Crisis, and Growth. Cambridge University Press, New York.

ODELL, Kerry and WEIDENMIER, Marc (2004): "Real Shock, Monetary Aftershock: The 1906 San Francisco Earthquake and the Panic of 1907”, Journal of Economic History, 64, nº pp. 1002-1027.

POWELL, Andrew, TAVELLA, Pilar (2012): “Capital Inflow Surges in Emerging Economies: How Worried Should LAC Be?”, IDB working paper 326, Washington, D.C.

REINHART, Carmen and REINHART, Vincent (2008): “Capital Flow Bonanzas: An Encompassing View of the Past and Present,” in FRANKEL, Jeffrey and PISSARIDES, Christopher. (eds.): NBER International Seminar on Macroeconomics 2008, University of Chicago Press, Chicago, pp. 9-62.

REINHART, Carmen and ROGOFF, Kenneth (2009): This Time is Different: Eight Centuries of Financial Folly. Princeton University Press, Princeton, New Jersey.

REINHART, Carmen, ROGOFF, Kenneth, and SAVASTANO, Miguel (2003): “Debt Intolerance”, Brookings Papers on Economic Activity ,1, pp. 1-74.

SCHULARICK, Moritz. and STEGER, Thomas. M. (2010): "Financial Integration, Investment, and Economic Growth: Evidence from Two Eras of Financial Globalization”, Review of Economics and Statistics, 92, n 4, pp. 756-768.

SCHULARICK, Moritz, TAYLOR Alan M. (2012): “Credit Booms Gone Bust: Monetary Policy, Leverage Cycles and Financial Crises, 1870-2008”, American Economic Review, 102, $\mathrm{n}^{\circ}$ 2, pp. 1029-1061.

STONE, Irving (1999): The Global Export of Capital from Great Britain, 1865-1914. StMartin’s Press, New York.

TATTARA, Giuseppe (2003): "Paper Money but a Gold Debt: Italy on the gold Standard”, Explorations in Economic History, 40, n² 2, pp. 122-142.

TAYLOR, Alan M. (2012): “The Great Leveraging”, NBER working paper 18290.

TAYLOR, Alan. M. (2002): “A Century of Current Account Dynamics”, Journal of International Money and Finance, 21, pp. 725-48. 
Figure 1 Growth Rate of Output Per Capita by Quintile

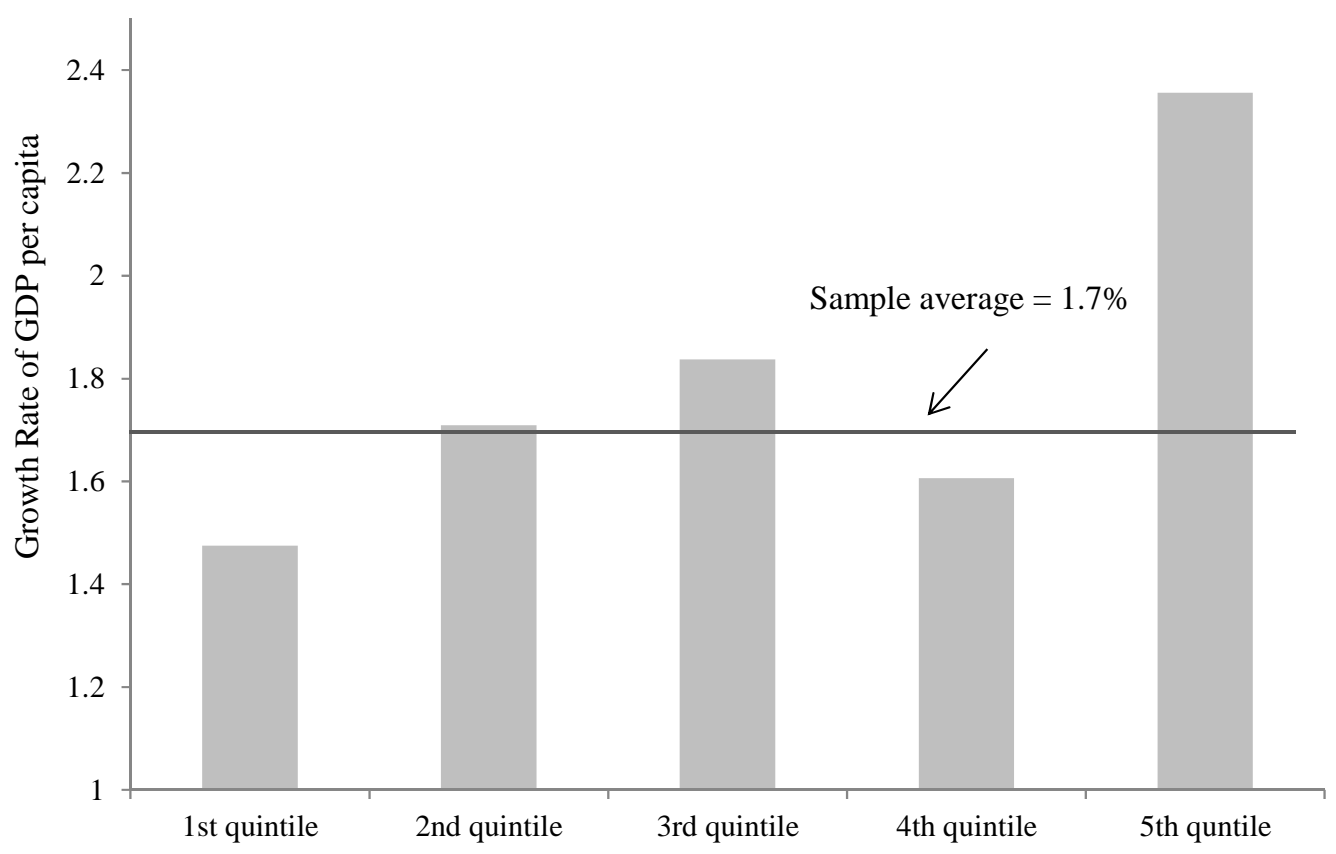

Notes: Quintiles are defined for a sample of 10 countries and are based on the ranking in the average ratio of capital calls on London (see text) relative to local GDP. The within country average is taken over the period 1880-1913. GDP per capita data are from Barro and Ursúa (2009).

Figure 2 Growth Rate of Consumption per Capita by Quintile

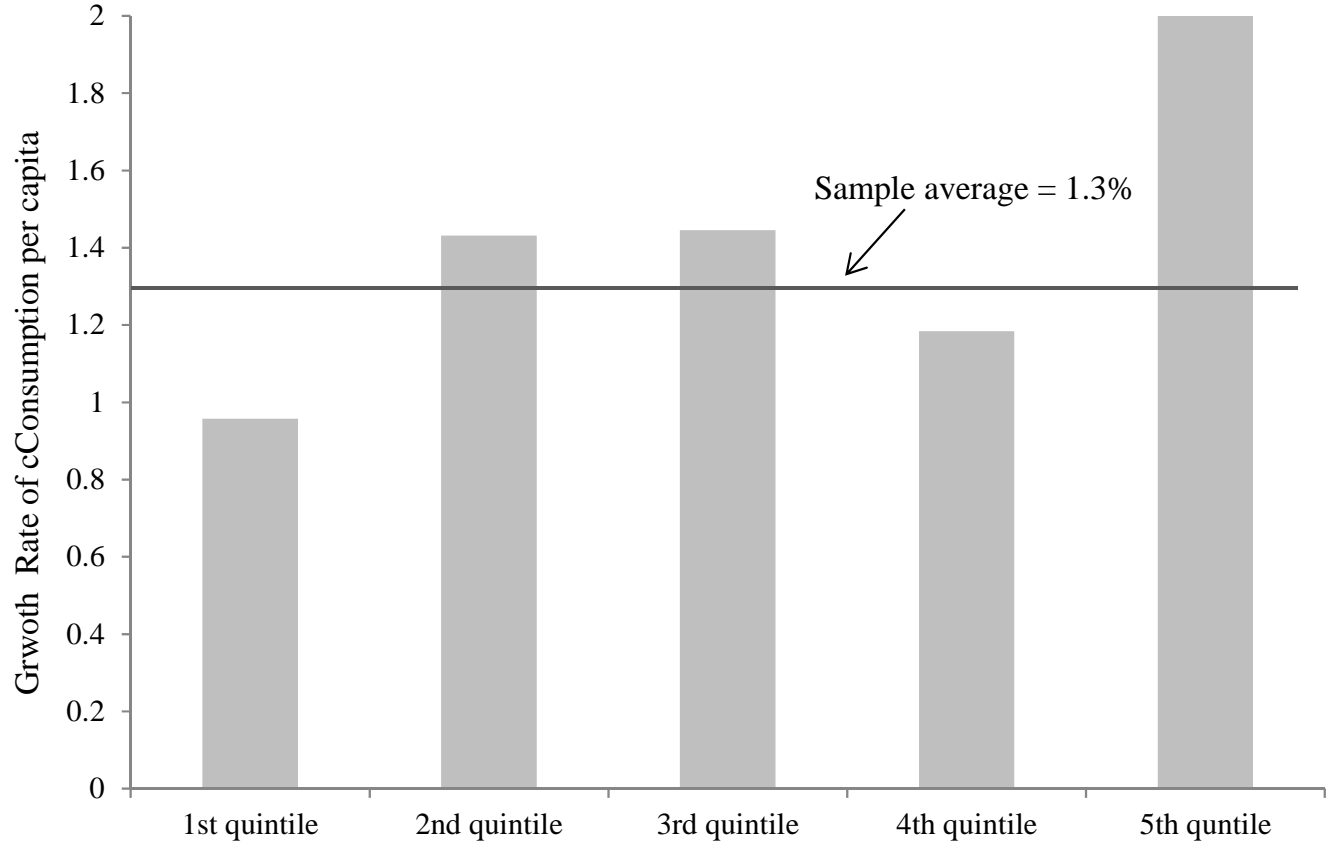

Notes: See notes for Figure 1. 
Figure 3 Investment/GDP by Quintile

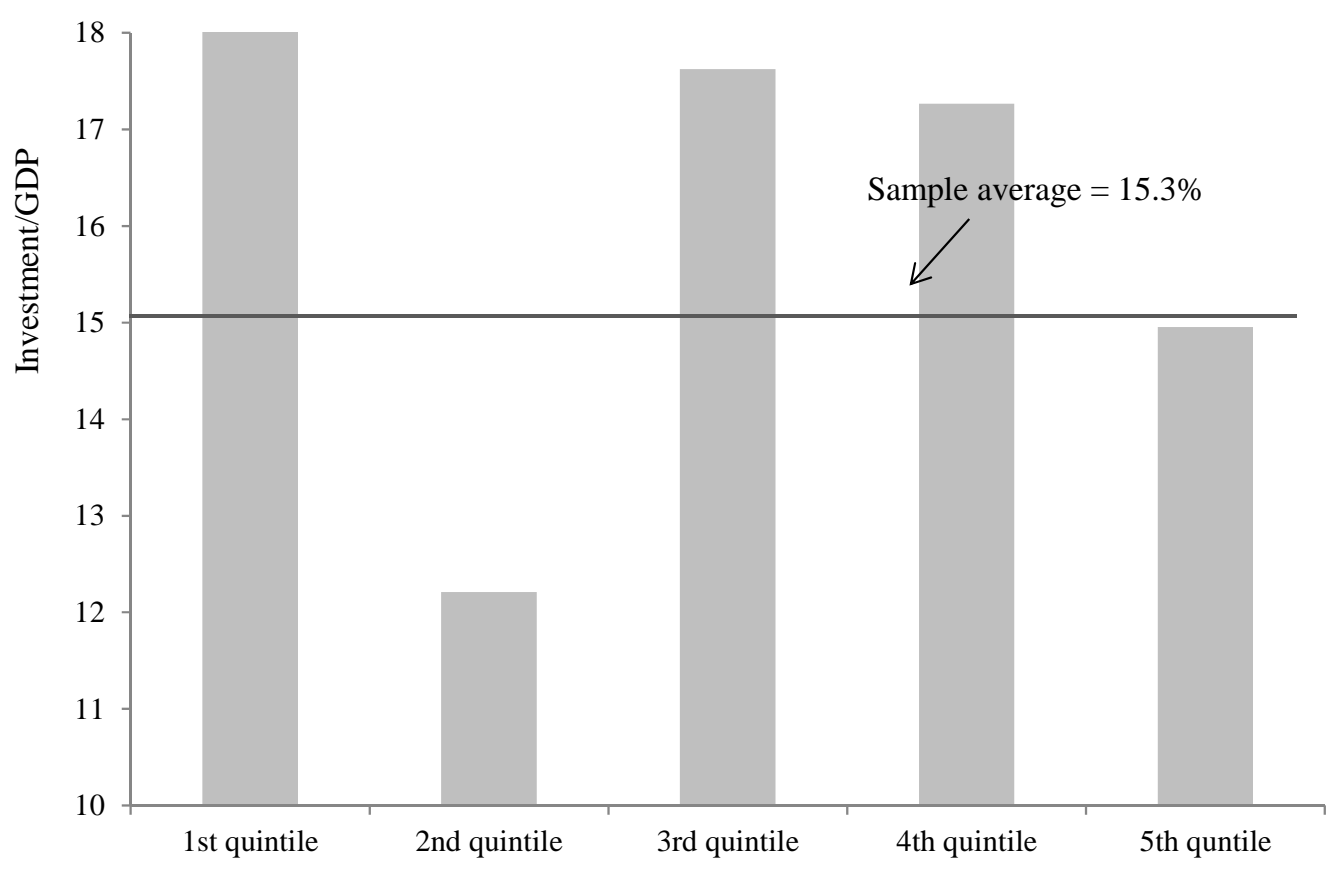

Notes: See notes to Figure 1 and text.

Figure 4 Standard Deviation of the Growth Rate of Output per capita by Quintile

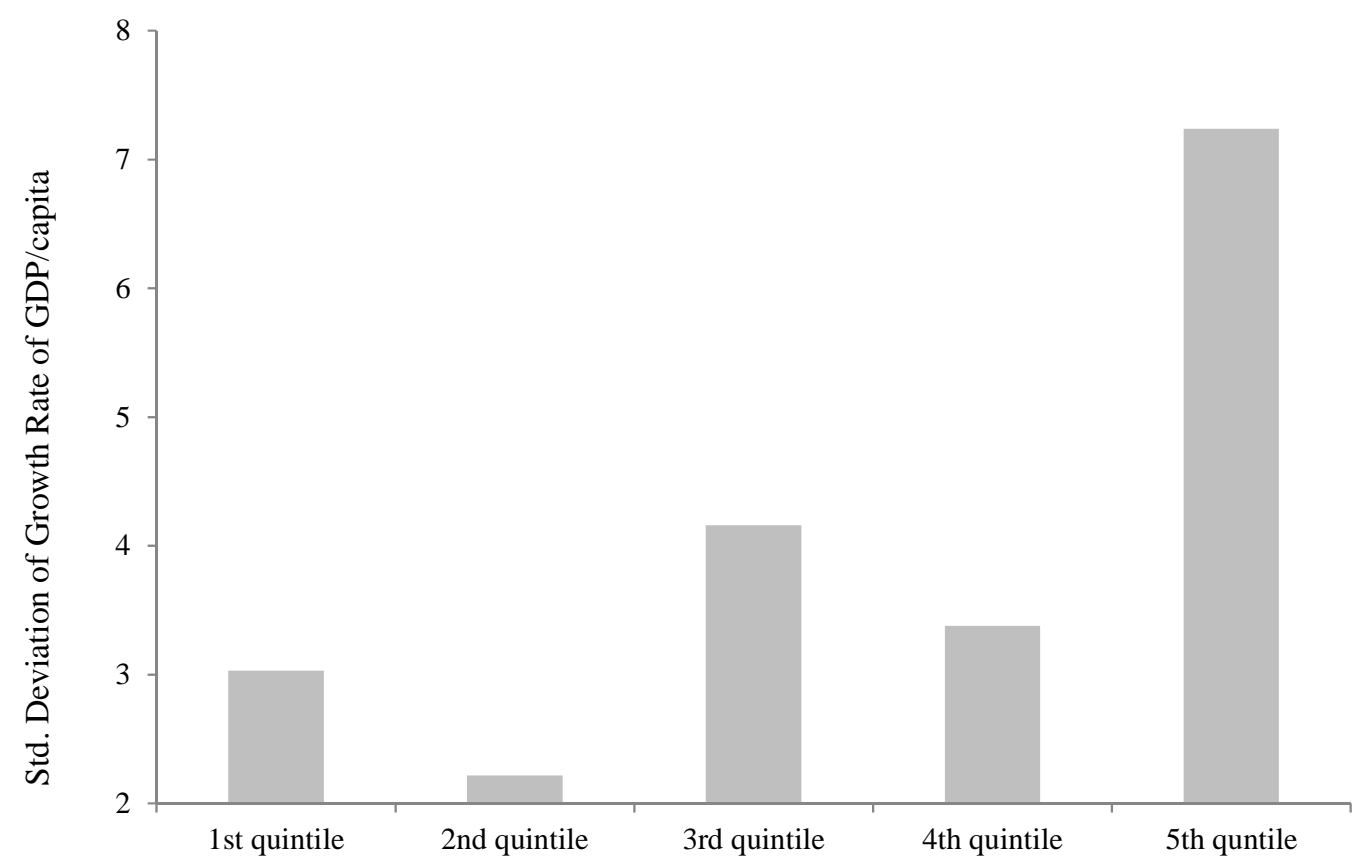

Notes: See notes to Figures 1 and 2. 
Figure 5 Standard Deviation of the Growth Rate of Consumption per capita by Quintile

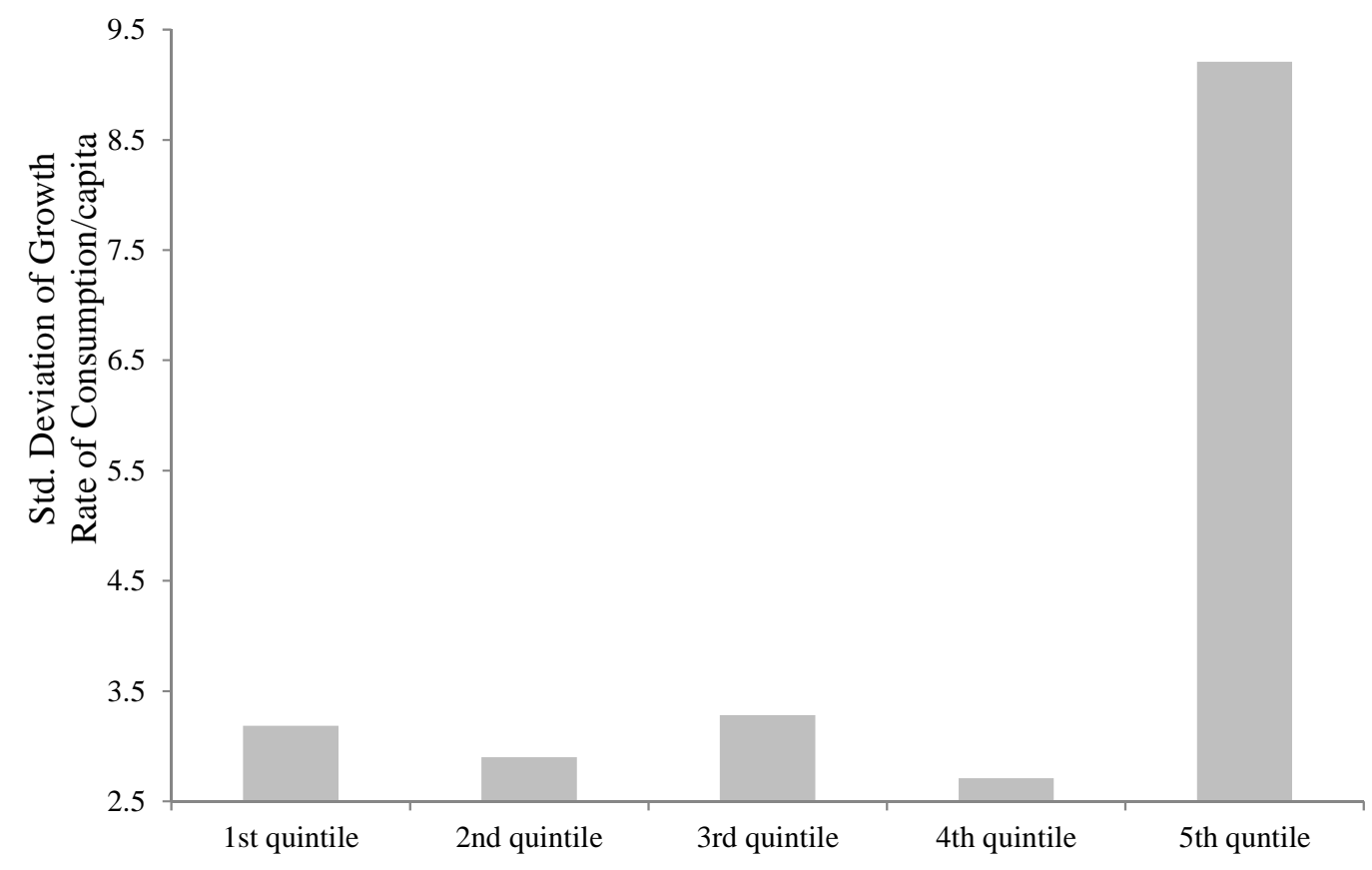

Notes: See notes to Figures 1 and 2. 
Figure 6 Average Output per Capita Before and after Crisis Events
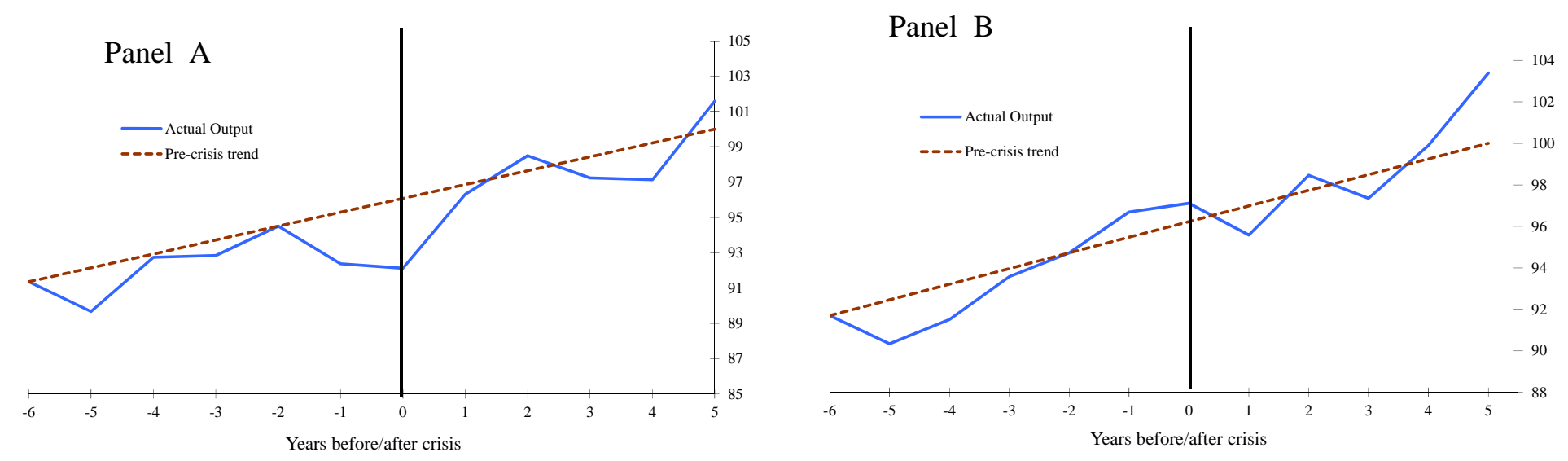

Panel C
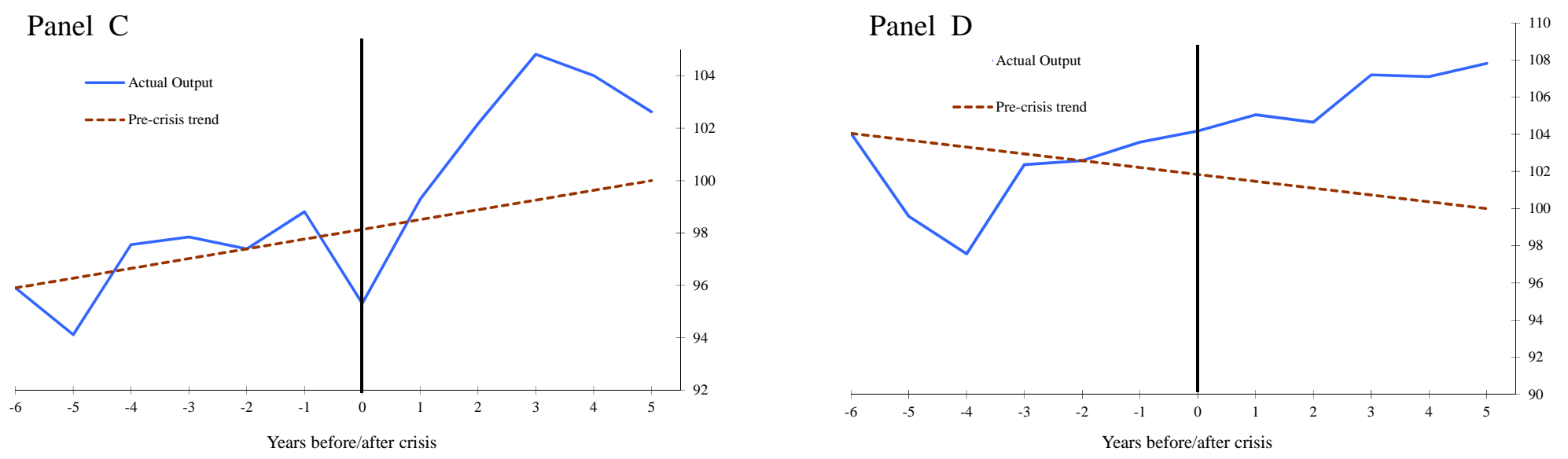

Notes: Panels are A) All crises, B) Banking crises, C) Currency Crises, D) Debt crises. Actual output is an average of the Barro-Ursúa per capita output index for all countries that had a crisis of the specified variety. The trends are calculated as the average growth rate of these same countries from the fifth year before the crisis until the second year before the crisis. 
Figure 7 Average Consumption per capita before and after crises
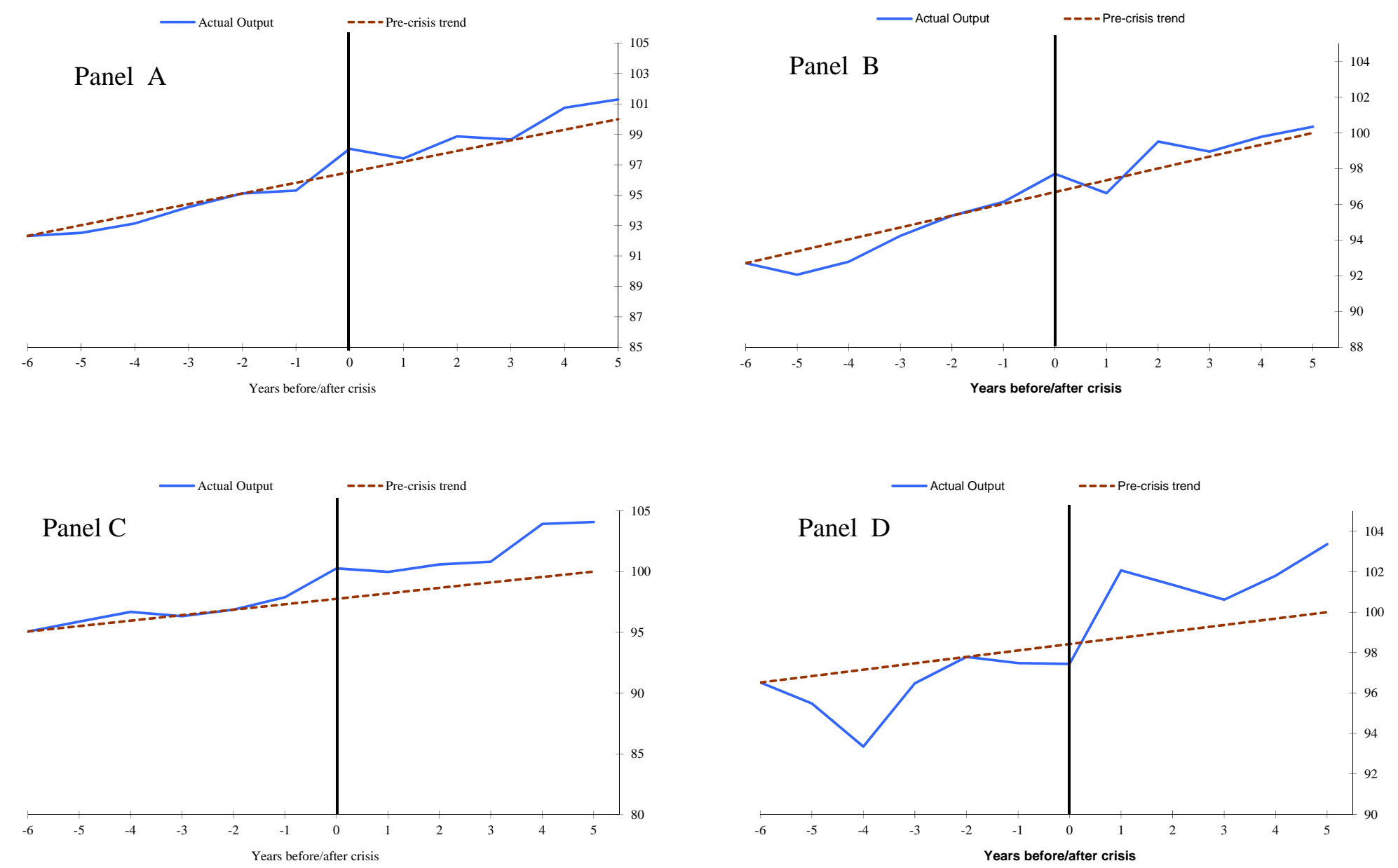

Notes: Panels are for A) All crises, B) Banking crises, C) Currency Crises, D) Debt crises. Actual output is an average of the Barro-Ursúa per capita output index for all countries that had a crisis of the specified variety. The trends are calculated as the average growth rate of these same countries from the fifth year before the crisis until the second year before the crisis. 
Figure 8 Average Ratio of Investment to GDP before and after crises
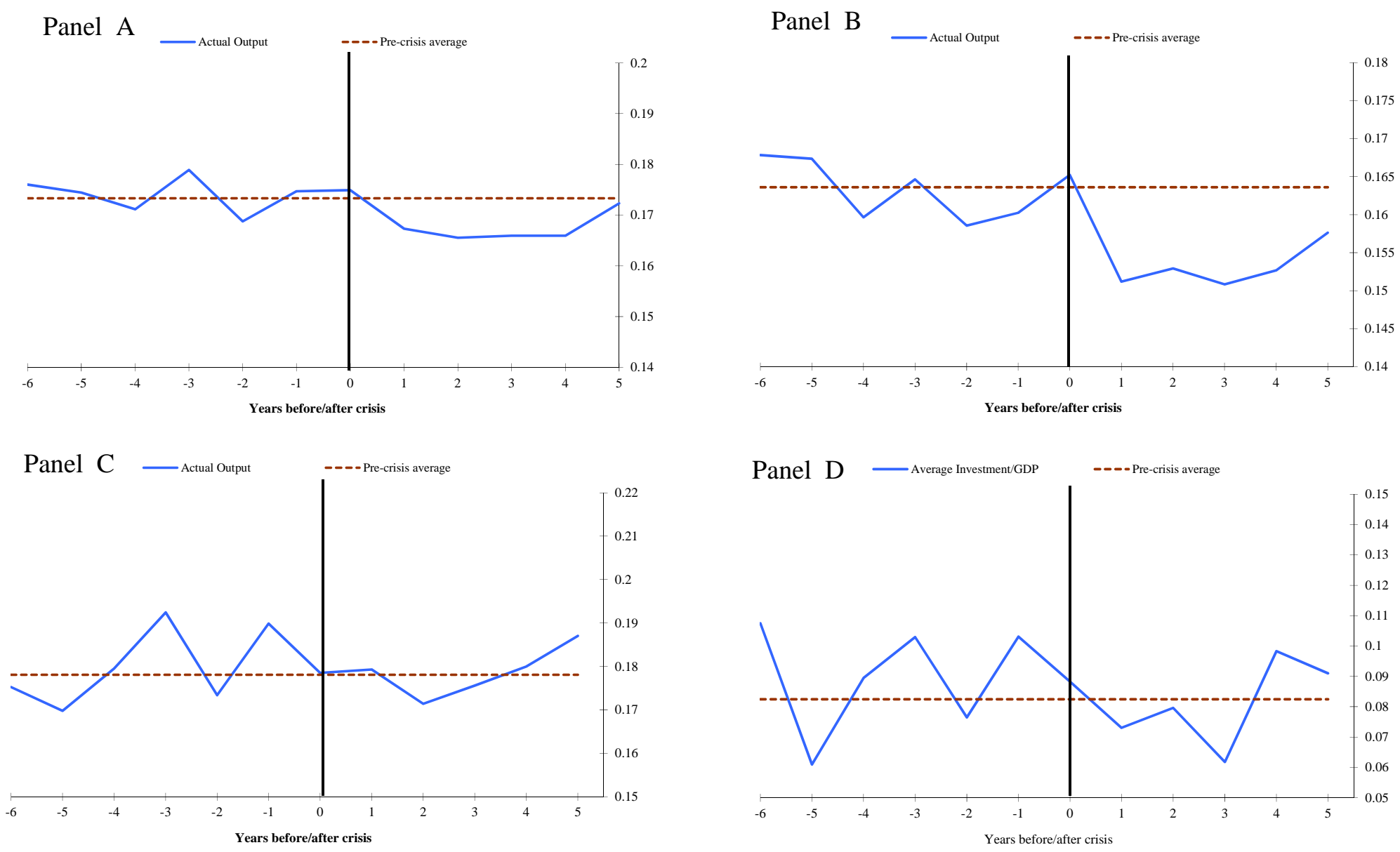

Notes: Panels A) All crises, B) Banking crises, C) Currency Crises, D) Debt crises. The averages are calculated as the average investment rate for these same countries from the fifth year before the crisis until the second year before the crisis. 
Figure 9 Crises and Booms for 14 Countries, 1880-1913

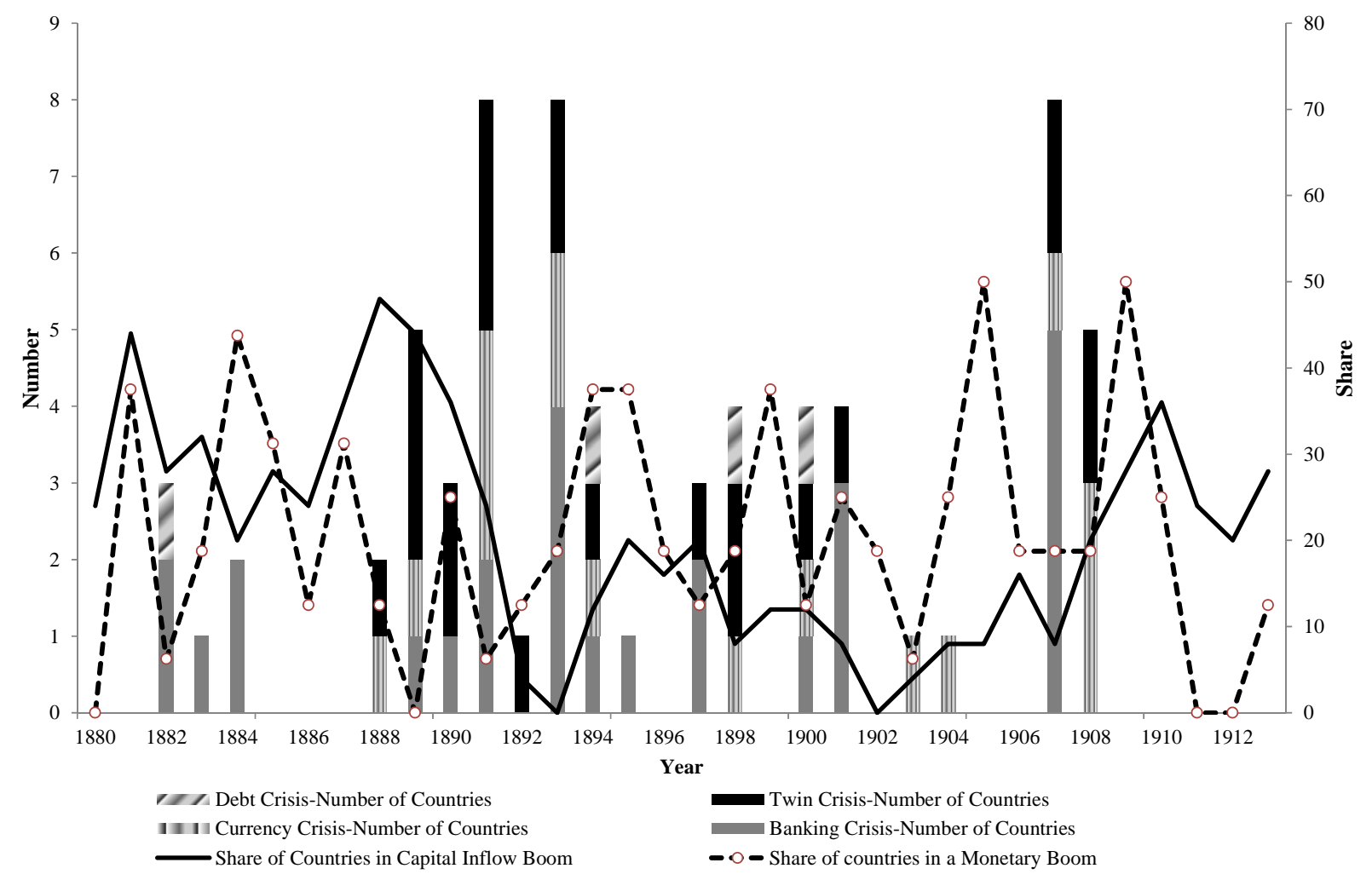

Notes: Data are for 14 countries with complete time series for money growth and capital inflows. 
Figure 10 Frequency of Banking Crises Conditional on an Inflow and Money Boom

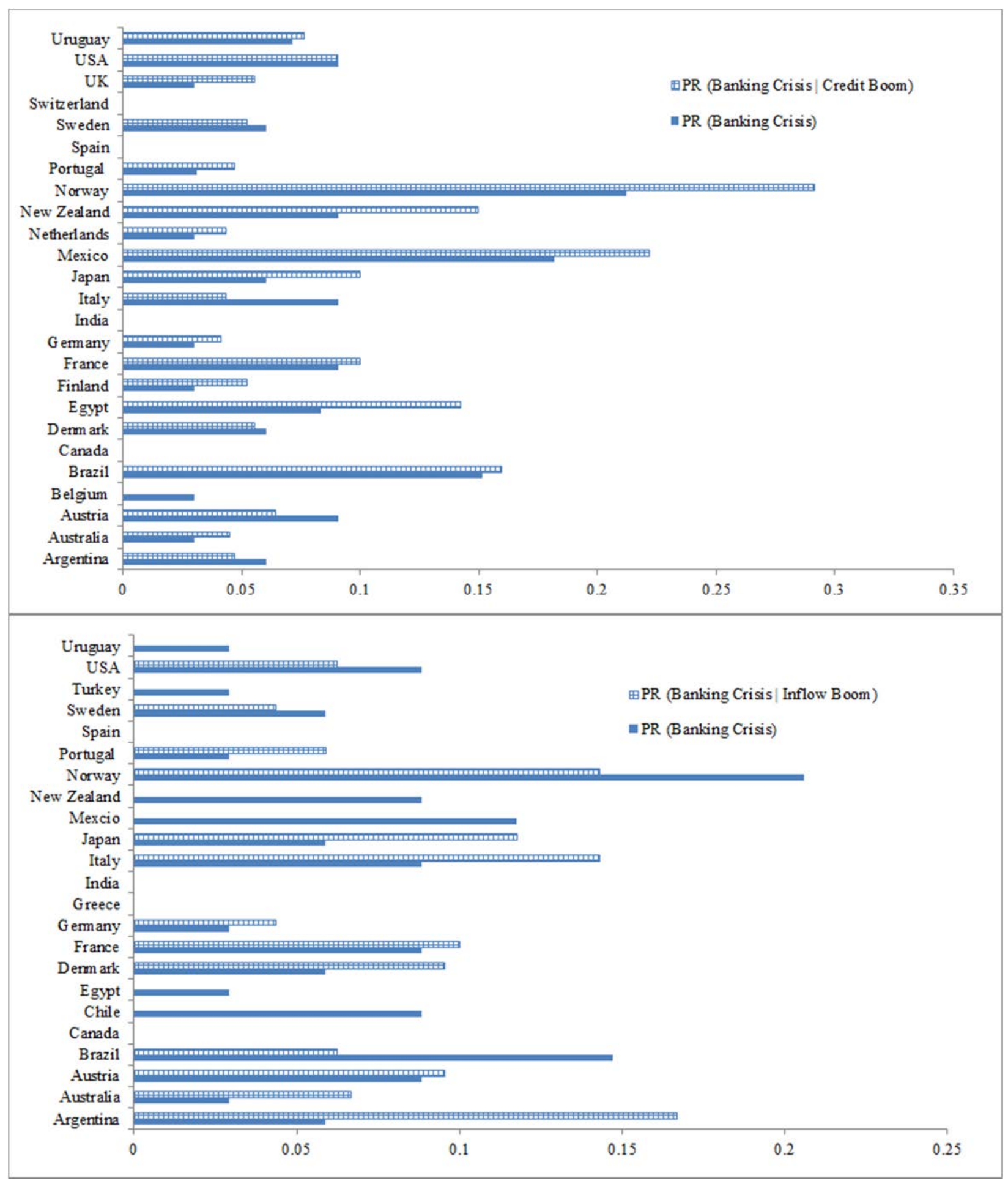

Notes: See the text for definition of a money or inflow boom. Conditional frequencies are given by the number of years in which a crisis occurs given there has been an inflow or money boom in the preceding or following three years divided by the number of years in which there has been a boom in the preceding or following three years. No bar indicates no crises. 
Figure 11 Frequency of Currency Crises Conditional on an Inflow or Money Boom
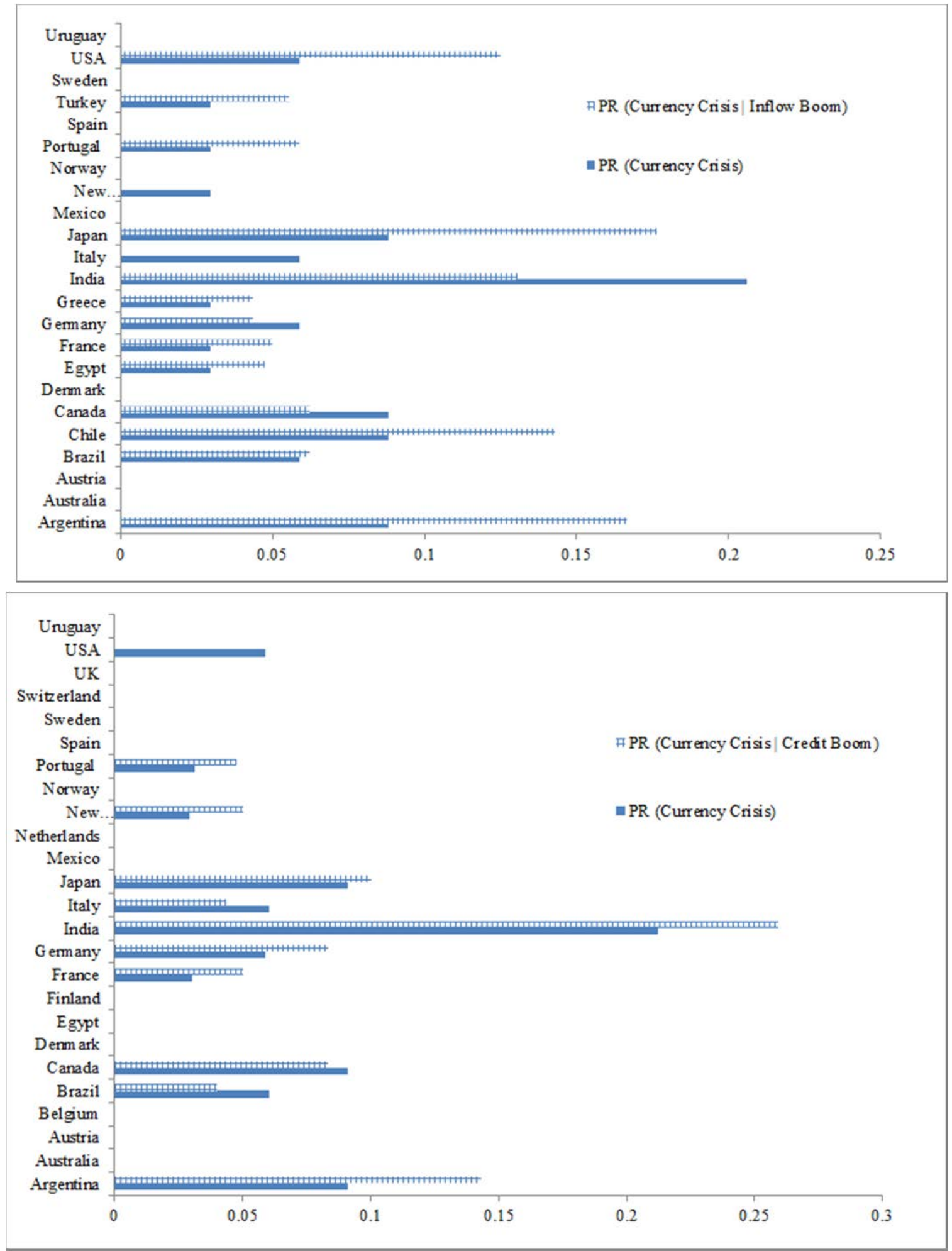

Notes: See notes to Figure 10. 


\section{Figure 12 Frequency of Any Kind of Crisis Conditional on an Inflow or Money Boom}

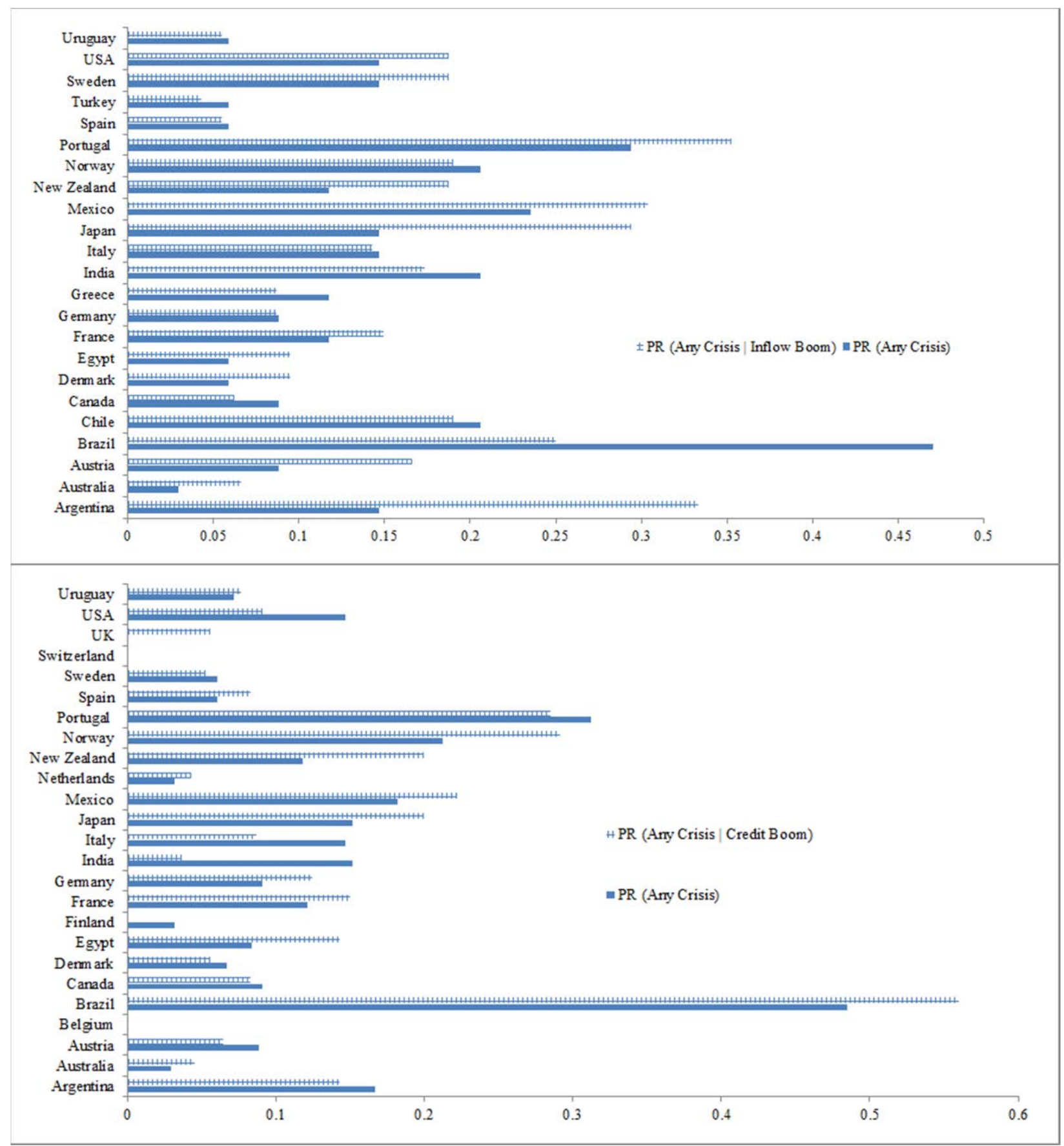

Notes: Any crisis is defined as a banking crisis, currency crisis, twin crisis (both banking and currency) or a debt crisis. See also notes to Figure 10. 
Table 1 Dates of Financial Crises, 1880-1913

\begin{tabular}{|c|c|}
\hline Country & Banking Crisis \\
\hline Argentina & 1890 \\
\hline Argentina & 1891 \\
\hline Australia & 1893 \\
\hline Austria & 1882 \\
Austria & 1883 \\
\hline Austria & 1884 \\
\hline Belgium & 1885 \\
\hline Brazil & 1890 \\
\hline Brazil & 1891 \\
\hline Brazil & 1897 \\
\hline Brazil & 1900 \\
\hline Brazil & 1901 \\
\hline Chile & 1889 \\
\hline Chile & 1898 \\
\hline Chile & 1907 \\
\hline Denmark & 1885 \\
\hline Denmark & 1907 \\
\hline Egypt & 1907 \\
\hline Finland & 1900 \\
\hline France & 1882 \\
\hline France & 1889 \\
\hline France & 1907 \\
\hline Germany & 1901 \\
\hline
\end{tabular}

\begin{tabular}{|c|c|}
\hline Country & Banking Crisis \\
\hline Italy & 1891 \\
Italy & 1893 \\
Italy & 1907 \\
\hline Japan & 1901 \\
\hline Japan & 1907 \\
\hline Mexico & 1884 \\
\hline Mexico & 1885 \\
Mexico & 1907 \\
\hline Mexico & 1908 \\
\hline Netherlands & 1897 \\
\hline New Zealand & 1893 \\
\hline New Zealand & 1894 \\
New Zealand & 1895 \\
\hline Portugal & 1891 \\
\hline Sweden & 1897 \\
\hline Sweden & 1907 \\
\hline Turkey & 1895 \\
\hline UK & 1890 \\
\hline USA & 1884 \\
\hline USA & 1893 \\
\hline USA & 1907 \\
\hline Uruguay & 1913 \\
\hline
\end{tabular}

\begin{tabular}{c|c}
\hline Country & Currency Crisis \\
\hline Argentina & 1885 \\
Argentina & 1890 \\
Argentina & 1908 \\
\hline Brazil & 1889 \\
Brazil & 1898 \\
\hline Canada & 1891 \\
Canada & 1893 \\
Canada & 1908 \\
\hline Chile & 1887 \\
\hline Chile & 1889 \\
\hline Chile & 1898 \\
\hline Egypt & 1900 \\
\hline France & 1888 \\
\hline Germany & 1893 \\
\hline
\end{tabular}

\begin{tabular}{|c|c|}
\hline Country & Currency Crisis \\
\hline Germany & 1907 \\
\hline Greece & 1885 \\
\hline India & 1891 \\
\hline Italy & 1894 \\
\hline Italy & 1908 \\
\hline Japan & 1900 \\
\hline Japan & 1904 \\
\hline Japan & 1908 \\
\hline New Zealand & 1903 \\
\hline Portugal & 1891 \\
\hline Russia & 1891 \\
\hline Turkey & 1886 \\
\hline Turkey & 1903 \\
\hline USA & 1891 \\
\hline
\end{tabular}

\begin{tabular}{|c|c|}
\hline Country & $\begin{array}{c}\text { Sovereign Debt } \\
\text { Crisis }\end{array}$ \\
\hline Argentina & 1890 \\
Brazil & 1898 \\
\hline Chile & 1880 \\
\hline Greece & 1894 \\
\hline Italy & 1894 \\
\hline Mexico & 1880 \\
\hline Portugal & 1892 \\
\hline
\end{tabular}

\begin{tabular}{|cc} 
Country & $\begin{array}{c}\text { Sovereign Debt } \\
\text { Crisis }\end{array}$ \\
\hline Russia & 1885 \\
\hline Spain & 1882 \\
\hline Spain & 1900 \\
\hline Turkey & 1880 \\
\hline Uruguay & 1891 \\
\hline
\end{tabular}

Notes: Sources for these dates are data Underlying Bordo, Eichengreen, Klingebiel, and Martínez-Peria (2001), Beim and Calomiris (2001) and Reinhart, Rogoff and Savastano (2003). The crisis in Belgium was not dated by BEKM but was highlighted by Buyst and Maes (2007). The debt default in Italy (1894) was discussed in Tattara (2003) and Spain (1900) in Comín (2012). 
Table 2 Dates of Capital Inflow Booms and Money Booms 1880-1913

\begin{tabular}{llll}
\multicolumn{1}{c}{ Country } & \multicolumn{1}{c}{ Capital Inflow Booms } & \multicolumn{1}{c}{ Country } & \multicolumn{1}{c}{ Money Booms } \\
\hline Argentina & $1883-84,1886-90$ & Argentina & $1886,1888,1899,1903-04,1908$ \\
\hline Australia & $1880,1883-87,1895$ & Australia & $1881,1887,1894-95,1909-10,1913$ \\
\hline Austria & $1881,1890,1895-96,1910-11,1913$ & Austria & $1881,1887,1892,1895,1900,1906,1910$ \\
\hline Brazil & $1883,1886,1888,1910-13$ & Belgium & $1894,1896-97,1904-05,1908,1913$ \\
Canada & $1885,1888,1908-10,1912,1913$ & Brazil & $1884,1887,1890,1901,1905,1909-10$ \\
\hline Chile & $1888-89,1895-96,1907,1911-1912$ & Canada & $1888,1894,1897,1899,1905-06,1909$ \\
\hline Denmark & $1881,1883,1899,1901,1908,1910,1912$ & Denmark & $1886-87,1893-94,1895,1901$ \\
\hline Egypt & $1881,1885,1899,1904,1905-07$ & Egypt & $1904-06$ \\
\hline France & $1881-82,1887,1891-92,1896-97$ & Finland & $1882,1886,1888,1893-96$ \\
\hline Germany & $1881-83,1888,1891,1897,1901$ & France & $1887-88,1892-93,1903-04,1907$ \\
Greece & $1881,1885,1887,1889-901898,1910$ & Germany & $1884,1886,1894-95,1902,1904,1908$ \\
\hline India & $1881-82,1887,1897-98,1900,1908$ & India & $1885,1887,1890,1894,1898,1905,1909$ \\
\hline Italy & $1881-82,1885,1887-89,1891$ & Italy & $1881,1884,1886,1899,1905,1908-09$ \\
\hline Japan & $1897,1899,1903-06,1909$ & Japan & $1890,1893,1895,1899,1902,1904-05$ \\
Mexico & $1882,1888-89,1894,1909-10,1913$ & Mexico & 1902,1906 \\
\hline New Zealand & $1880,1883-86,1888,1895$ & Netherlands & $1886,1892,1894-95,1897,1905,1908$ \\
\hline Norway & $1880,1886-87,1900,1909,1911,1913$ & New Zealand & $1881-82,1895,1905-07,1910$ \\
\hline Portugal & $1880-81,1884-85,1889,1890,1894$ & Norway & $1884-85,1890,1901-02,1907,1909$ \\
\hline Russia & $1890,1906,1909-13$ & Portugal & $1883,1886-89,1895,1910$ \\
\hline Spain & $1880,1883-84,1888-89,1890,1897$ & Spain & $1883-1885,1891,1896,1898,1909$ \\
\hline Sweden & $1881,1886,1888,18889,1900,1908-09$ & Sweden & $1883-85,1893,1899,1900-01$ \\
\hline Turkey & $1888-89,1891,1894-95,1909-10$ & Switzerland & $1884-85,1896,1902,1905,1906,1909$ \\
\hline USA & $1880-82,1887,1889,1890,1913$ & UK & $1881,1884-85,1894-96,1899$ \\
\hline Uruguay & $1883,1887-91,1896$ & USA & $1881,1883,1898,1899,1901,1905,1909$ \\
\hline & & Uruguay & $1902,1908,1911$ \\
\hline
\end{tabular}

Notes: Capital inflow booms are defined as ratios of capital calls on London to GDP above the within country $80^{\text {th }}$ percentile between $1880-1913$. Money booms are defined as growth in the real money supply above the $80^{\text {th }}$ percentile within a country between 1880 and 1913. 
Table 3 Capital Inflow Booms and Money Booms as Determinants of Banking, Currency and “All” types of Financial Crises

\begin{tabular}{|c|c|c|c|c|c|c|c|c|c|}
\hline & $\begin{array}{c}\text { Currency } \\
\text { Crisis }\end{array}$ & $\begin{array}{c}\text { Banking } \\
\text { Crisis } \\
\end{array}$ & All Crises & $\begin{array}{c}\text { Currency } \\
\text { Crisis }\end{array}$ & $\begin{array}{c}\text { Banking } \\
\text { Crisis }\end{array}$ & All Crises & $\begin{array}{c}\text { Currency } \\
\text { Crisis }\end{array}$ & $\begin{array}{c}\text { Banking } \\
\text { Crisis } \\
\end{array}$ & $\begin{array}{c}\text { All } \\
\text { Crises } \\
\end{array}$ \\
\hline Inflow Boom t-1 & $\begin{array}{c}0.75 \\
{[0.534]}\end{array}$ & $\begin{array}{c}-0.53 \\
{[0.527]}\end{array}$ & $\begin{array}{c}-0.23 \\
{[0.317]}\end{array}$ & $\begin{array}{c}0.96 \\
{[0.651]}\end{array}$ & $\begin{array}{c}-0.51 \\
{[0.573]}\end{array}$ & $\begin{array}{c}-0.09 \\
{[0.395]}\end{array}$ & --- & --- & --- \\
\hline Inflow Boom t-2 & $\begin{array}{c}0.24 \\
{[0.638]}\end{array}$ & $\begin{array}{l}1.07 * * * \\
{[0.404]}\end{array}$ & $\begin{array}{c}0.70^{*} \\
{[0.404]}\end{array}$ & $\begin{array}{c}0.24 \\
{[0.750]}\end{array}$ & $\begin{array}{l}1.09 * * * \\
{[0.386]}\end{array}$ & $\begin{array}{c}0.69 \\
{[0.424]}\end{array}$ & --- & --- & --- \\
\hline Inflow Boom t-3 & $\begin{array}{c}0.22 \\
{[0.495]}\end{array}$ & $\begin{array}{c}0.35 \\
{[0.444]}\end{array}$ & $\begin{array}{c}0.32 \\
{[0.381]}\end{array}$ & $\begin{array}{c}-0.1 \\
{[0.545]}\end{array}$ & $\begin{array}{c}0.07 \\
{[0.538]}\end{array}$ & $\begin{array}{c}0.04 \\
{[0.422]}\end{array}$ & --- & --- & --- \\
\hline Money/Credit Boom t & $\begin{array}{c}-0.84 \\
{[0.816]}\end{array}$ & $\begin{array}{c}-0.36 \\
{[0.435]}\end{array}$ & $\begin{array}{c}-0.67 \\
{[0.419]}\end{array}$ & $\begin{array}{c}-0.68 \\
{[0.780]}\end{array}$ & $\begin{array}{c}-0.14 \\
{[0.447]}\end{array}$ & $\begin{array}{c}-0.55 \\
{[0.399]}\end{array}$ & --- & --- & --- \\
\hline Money/Credit Boom t-1 & $\begin{array}{c}0.25 \\
{[0.385]}\end{array}$ & $\begin{array}{c}0.63 \\
{[0.433]}\end{array}$ & $\begin{array}{c}0.35 \\
{[0.273]}\end{array}$ & $\begin{array}{c}0.23 \\
{[0.430]}\end{array}$ & $\begin{array}{c}0.72 * \\
{[0.398]}\end{array}$ & $\begin{array}{c}0.47^{*} \\
{[0.276]}\end{array}$ & --- & --- & --- \\
\hline Money/Credit Boom t-2 & $\begin{array}{c}0.36 \\
{[0.504]}\end{array}$ & $\begin{array}{c}0.12 \\
{[0.351]}\end{array}$ & $\begin{array}{c}0.27 \\
{[0.290]}\end{array}$ & $\begin{array}{c}0.09 \\
{[0.591]}\end{array}$ & $\begin{array}{c}-0.23 \\
{[0.368]}\end{array}$ & $\begin{array}{c}0.13 \\
{[0.333]}\end{array}$ & --- & --- & --- \\
\hline Money/Credit Boom t-3 & $\begin{array}{c}0.75 \\
{[0.534]}\end{array}$ & $\begin{array}{c}-0.53 \\
{[0.527]}\end{array}$ & $\begin{array}{c}-0.23 \\
{[0.317]}\end{array}$ & $\begin{array}{c}0.96 \\
{[0.651]}\end{array}$ & $\begin{array}{c}-0.51 \\
{[0.573]}\end{array}$ & $\begin{array}{c}-0.09 \\
{[0.395]}\end{array}$ & --- & --- & --- \\
\hline Capital Inflows/GDP t-1 & --- & --- & --- & --- & --- & --- & $\begin{array}{c}0.11^{* * *} \\
{[0.025]}\end{array}$ & $\begin{array}{l}0.08 * * \\
{[0.034]}\end{array}$ & $\begin{array}{c}0.05 \\
{[0.033]}\end{array}$ \\
\hline Growth $(\mathrm{M} / \mathrm{P}) \mathrm{t}-1$ & --- & --- & --- & --- & --- & --- & $\begin{array}{c}-0.89 \\
{[1.972]}\end{array}$ & $\begin{array}{c}0.5 \\
{[0.862]}\end{array}$ & $\begin{array}{c}-0.59 \\
{[1.089]}\end{array}$ \\
\hline Foreign Currency Debt/Total Debt & --- & --- & --- & $\begin{array}{c}-0.3 \\
{[0.720]}\end{array}$ & $\begin{array}{c}0.41 \\
{[0.483]}\end{array}$ & $\begin{array}{c}0.43 \\
{[0.437]}\end{array}$ & $\begin{array}{c}-0.83 \\
{[0.737]}\end{array}$ & $\begin{array}{c}0.03 \\
{[0.575]}\end{array}$ & $\begin{array}{c}0.24 \\
{[0.506]}\end{array}$ \\
\hline Gold Standard dummy & --- & --- & --- & $\begin{array}{c}-0.16 \\
{[0.596]}\end{array}$ & $\begin{array}{c}-0.09 \\
{[0.664]}\end{array}$ & $\begin{array}{c}-0.55 \\
{[0.549]}\end{array}$ & $\begin{array}{c}0.12 \\
{[0.644]}\end{array}$ & $\begin{array}{c}0.04 \\
{[0.667]}\end{array}$ & $\begin{array}{c}-0.48 \\
{[0.544]}\end{array}$ \\
\hline GB discount rate & --- & --- & --- & $\begin{array}{c}0.87 * * \\
{[0.347]}\end{array}$ & $\begin{array}{c}0.67^{*} \\
{[0.403]}\end{array}$ & $\begin{array}{c}0.39 \\
{[0.360]}\end{array}$ & $\begin{array}{c}0.87 * * * \\
{[0.334]}\end{array}$ & $\begin{array}{l}0.70 * * \\
{[0.349]}\end{array}$ & $\begin{array}{c}0.43 \\
{[0.347]}\end{array}$ \\
\hline Banking Crisis t- 1 & --- & --- & --- & $\begin{array}{c}1.23 \\
{[0.832]}\end{array}$ & $\begin{array}{c}1.62 * \\
{[0.893]}\end{array}$ & $\begin{array}{l}1.82 * * * \\
{[0.566]}\end{array}$ & $\begin{array}{c}1.21 \\
{[0.860]}\end{array}$ & $\begin{array}{c}1.61^{* *} \\
{[0.752]}\end{array}$ & $\begin{array}{l}1.78 * * * \\
{[0.494]}\end{array}$ \\
\hline Currency Crisis t-1 & --- & --- & --- & & $\begin{array}{c}1.36 * * \\
{[0.556]}\end{array}$ & $\begin{array}{c}1.67 * * * \\
{[0.480]}\end{array}$ & & $\begin{array}{c}1.53^{* *} \\
{[0.618]}\end{array}$ & $\begin{array}{l}1.71^{* * *} \\
{[0.513]}\end{array}$ \\
\hline $\begin{array}{l}\text { p-value test sum of Inflow Boom }=0 \\
\text { p-value test sum of Money Boom }=0 \\
\text { Observations }\end{array}$ & $\begin{array}{l}0.77 \\
0.77 \\
486\end{array}$ & $\begin{array}{l}0.27 \\
0.63 \\
486\end{array}$ & $\begin{array}{l}0.22 \\
0.92 \\
486\end{array}$ & $\begin{array}{l}0.10 \\
0.69 \\
486\end{array}$ & $\begin{array}{l}0.32 \\
0.65 \\
486\end{array}$ & $\begin{array}{l}0.28 \\
0.93 \\
486\end{array}$ & $\begin{array}{l}--- \\
--- \\
486\end{array}$ & $\begin{array}{l}--- \\
--- \\
486\end{array}$ & $\begin{array}{l}--- \\
--- \\
486\end{array}$ \\
\hline
\end{tabular}

Notes: Coefficients are estimated by maximum likelihood in a series of logit models. Robust standard errors are in brackets. 